\title{
Silicon enhancement of estimated plant biomass carbon accumulation under abiotic and biotic stresses. A meta-analysis
}

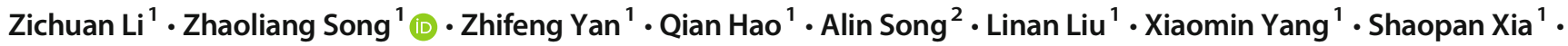 \\ Yongchao Liang ${ }^{3}$
}

Accepted: 8 March 2018 / Published online: 2 May 2018

C INRA and Springer-Verlag France SAS, part of Springer Nature 2018

\begin{abstract}
Abiotic and biotic stresses are the major factors limiting plant growth worldwide. Plants exposed to abiotic and biotic stresses often cause reduction in plant biomass as well as crop yield, resulting in plant biomass carbon loss. As a beneficial and quasiessential element, silicon accumulation in rhizosphere and plants can alleviate the unfavorable effects of the major forms of abiotic and biotic stress through several resistance mechanisms and thus increases plant biomass accumulation and crop yield. The beneficial effects of silicon on plant growth and crop yield have been widely reviewed over the last years. However, carbon accumulation of silicon-associated plant biomass under abiotic and biotic stresses has not yet been systematically addressed. This review article focuses on both the main mechanisms of silicon-mediated alleviation of abiotic and biotic stresses and their effects on plant biomass carbon accumulation in terrestrial ecosystems. The major points are the following: (1) the recovery of plant biomass via silicon mediation usually exhibits a bell-shaped response curve to abiotic stress severity and an S-shaped response curve to biotic stress severity; (2) although carbon concentration of plant biomass decreases with silicon accumulation, more than $96 \%$ of the recovered plant biomass contributes to plant biomass carbon accumulation; (3) silicon-mediated recovery generally increases plant biomass carbon by $35 \%$ and crop yield by $24 \%$. In conclusion, silicon can improve plant growth and enhance plant biomass carbon accumulation under abiotic and biotic stresses in terrestrial ecosystems.
\end{abstract}

Keywords Abiotic stresses $\cdot$ Biotic stresses $\cdot$ Carbon accumulation $\cdot$ Plant biomass restoration $\cdot$ Silicon

Zhaoliang Song

songzhaoliang78@163.com

Yongchao Liang

ycliang@zju.edu.cn

1 Institute of Surface-Earth System Science, Tianjin University, Tianjin 300072, China

2 Key Laboratory of Crop Nutrition and Fertilization, Institute of Agricultural Resources and Regional Planning, Chinese Academy of Agricultural Sciences, Beijing 100081, China

3 Ministry of Education Key Laboratory of Environment Remediation and Ecological Health, College of Environmental and Resource Sciences, Zhejiang University, Hangzhou 310058, China

\section{Contents}

1 Introduction

2 Materials and methods

2.1 Data compilation

2.2 Data calculation

2.3 Data analysis

3 Plant biomass carbon accumulation under abiotic and biotic stresses

3.1 Abiotic stresses

3.2 Biotic stresses

4 Silicon distribution in plants and its alleviation of stresses

4.1 Silicon distribution and accumulation in plants

4.2 Silicon alleviation of abiotic stresses

4.3 Silicon regulation of biotic stresses

5 Silicon enhancement of plant biomass carbon accumulation under stresses

5.1 Silicon enhancement of carbon accumulation under abiotic stresses

5.2 Silicon enhancement of carbon accumulation under biotic stresses 
6 Implications for the management of terrestrial ecosystems

7 Conclusions and perspectives

Acknowledgements

References

\section{Introduction}

Abiotic and biotic stresses are the important factors limiting plant growth and crop yield worldwide. The drought and salt stresses are the two major abiotic stress factors that restrict plant growth and productivity (Cramer et al. 2011; Zhu 2016), while pathogen infection and animal grazing are the two major biotic stress factors that cause plant injuries and biomass losses (Massey et al. 2007; Dow et al. 2017). The area subject to meteorological drought constitutes about $21 \%$ of the earth's land area, with nearly $13 \%$ under moderate to severe conditions (Prudhomme et al. 2014; Damberg and AghaKouchak 2014), whereas the area suffering from soil salinization accounts for approximately $7 \%$ of the global land area and $20 \%$ of the total cropland area (Rasool et al. 2013). Other forms of abiotic stress, such as soil acidification (Sumner and Noble 2003), heavy metal contamination (Adrees et al. 2015), UV radiation (Jansen and van den Noort 2000), extreme temperature (Levitt 1980), and nutrient imbalance (Huber et al. 2012), also have negative effects on plant growth. Among the biotic stresses, fungal pathogen contributes to $70-80 \%$ of plant diseases (Ray et al. 2017), while bacterial or viral pathogens usually have a long latent period and cause fatal plant injuries (García and Pallás 2015; Kim et al. 2016). Insect infestation and herbivore grazing often lead to tissue losses, which are more costly to renovate for slowgrowing plant species (Massey et al. 2007). The negative effects of abiotic and biotic stresses have been reported to reduce crop yield and plant biomass carbon through restraining plant photosynthesis and biomass accumulation (Eneji et al. 2008; Nicol et al. 2011). Additionally, climatic and environmental changes may cause more severe and frequent occurrences of abiotic and biotic stresses in the future.

Traditional measures to alleviate abiotic and biotic stresses may have some negative environmental and ecological effects (e.g., pesticide residues). Alternatively, many studies have demonstrated that silicon (Si) accumulation in plants can increase the adaptive capacity of plants under abiotic and biotic stresses (Tuna et al. 2008; Kim et al. 2014; Kang et al. 2016; Song et al. 2016) (Fig. 1). Silicon that is tightly bound to the cell walls is naturally present as a structural material in relation to enhancement of cell wall rigidity and elasticity (Weiss and Herzog 1978; He et al. 2013). When monosilicic acid concentration is high in the xylem sap, it becomes an important osmolyte improving plant osmotic and water potentials
(Casey et al. 2004; Mitani et al. 2005; Yin et al. 2013). In addition, Si requires relatively less energy than the biomolecules such as lignin and proline with regard to structural material and osmolyte (Raven 2001; Broadley et al. 2012). Therefore, Si can improve the homeostasis of plant resistance to multiple abiotic and biotic stresses in terrestrial ecosystems at a low cost.

Important literature has reported that $\mathrm{Si}$ application can promote plant growth, biomass accumulation, and crop yield under various abiotic (Liang et al. 2007; Cooke and Leishman 2016; Rios et al. 2017) and biotic (Hartley and DeGabriel 2016; Luyckx et al. 2017; Wang et al. 2017) stresses. Recently, researches on molecular mechanisms of Si uptake, transport, and accumulation in plants have achieved a critical milestone in molecular evolution of aquaporins (Deshmukh et al. 2015; Yamaji et al. 2015; Vivancos et al. 2016). However, the linkage between the mechanism of Si-mediated alleviation and the effect of $\mathrm{Si}$ on plant biomass carbon accumulation in terrestrial ecosystems has not yet been clarified accurately. Different from other reviews focusing on the mechanisms of $\mathrm{Si}$-mediated resistance to various stresses (Guntzer et al. 2012; Zhu and Gong 2014; Rizwan et al. 2015; Imtiaz et al. 2016), this review summarizes and discusses the mechanisms on how $\mathrm{Si}$ improves plant biomass carbon accumulation under abiotic and biotic stresses. First, we introduce the negative effects of various stresses on plant biomass carbon accumulation as abiotic and biotic stresses severely suppress plant growth. Second, we make the connection between the physiological mechanisms of Si-mediated alleviation under different stresses and the factors controlling $\mathrm{Si}$ enhancement of plant biomass carbon accumulation. Third, we discuss the role of $\mathrm{Si}$ in enhancing aboveground net primary productivity (ANPP) and plant biomass carbon accumulation in terrestrial ecosystems. Finally, we discuss the potential of $\mathrm{Si}$ in enhancing plant biomass carbon accumulation for future investigation at the ecosystem scale.

\section{Materials and methods}

\subsection{Data compilation}

Data on Si-mediated recovery of plant biomass and crop yield under abiotic and biotic stresses were collected from peerreviewed publications. In order to avoid publication bias, the following keywords were employed to search the Web of Science: silicon, abiotic stresses (i.e., drought stress, salt stress, UV-B radiation, nutritional imbalance, and heavy metal toxicities), and biotic stresses (i.e., bacterial blight, brown 
Fig. 1. Beneficial effect of $\mathrm{Si}$ application to rice growth under salt stress (a) and common $\mathrm{Si}-$ accumulating crops: rice (b), cucumber (c), and wheat (d). In sub-figure (a), Si-0, Si-5, Si-10, and Si-20 denote $0,5,10$, and $20 \mathrm{~g}$ Si fertilizer per pot, respectively

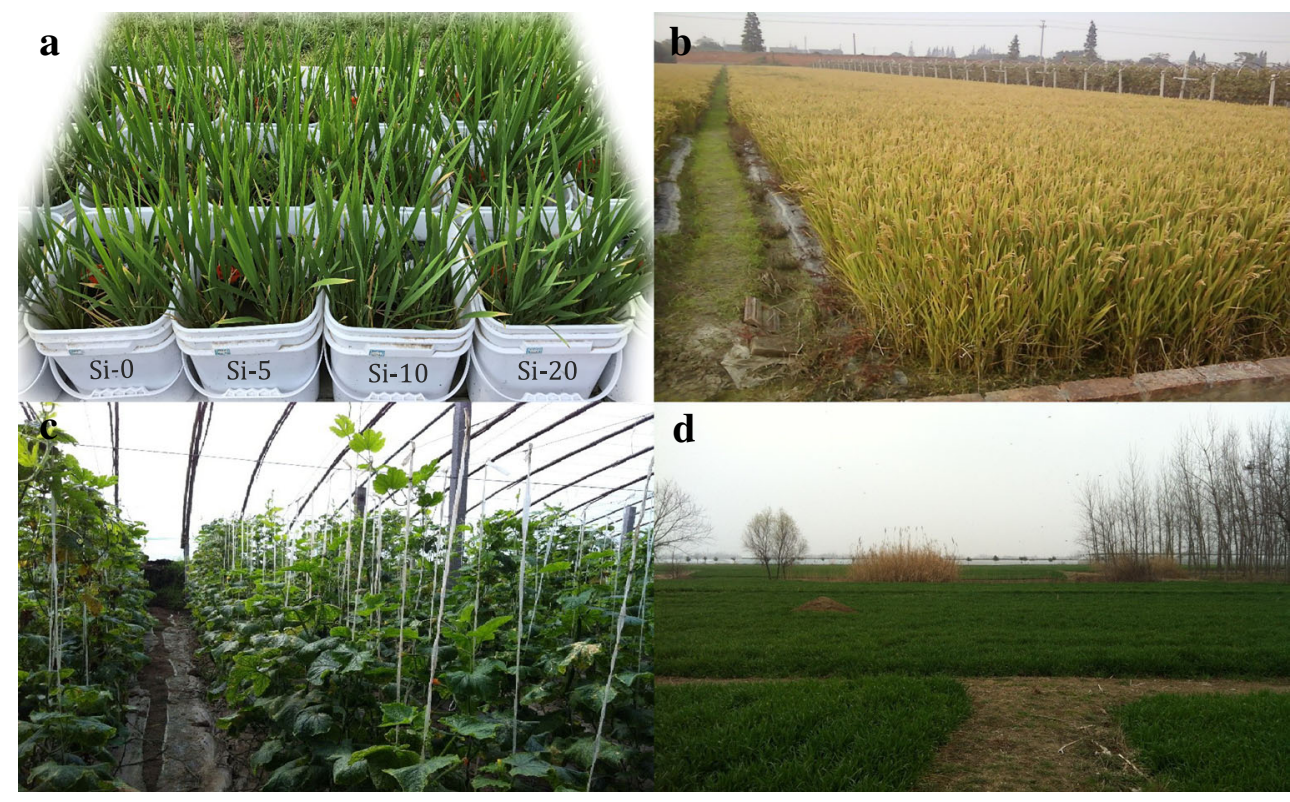

spot, stalk borer, and neck blast). In addition, the following two criteria were used to select literatures for analysis:

1. Plant biomass was provided or could be calculated based on dry weight of leaf, grain, stalk, and root;

2. Crop yields were provided.

Plant biomass included aboveground biomass only or was comprised of below- and aboveground biomass. In total, 41 papers dealing with plant biomass and 12 papers dealing with crop yield were selected in our synthesis. The original data of plant growth with and without $\mathrm{Si}$ application under various stress conditions were extracted from reported tables or graphs using GetData Graph Digitizer (Version 2.22, Russian Federation).

\subsection{Data calculation}

Because the control treatment of $\mathrm{Si}$ application usually displays enhancement of plant biomass accumulation as well, in order to preclude the $\mathrm{Si}$ fertilization effect, plant biomass increment (PBI) mediated by $\mathrm{Si}$ application under both abiotic and biotic stresses was calculated using Eq. (1).

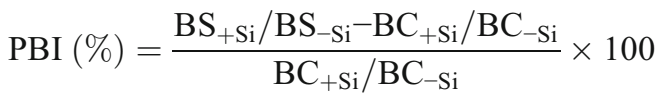

where BS is the plant biomass under stressful condition, $\mathrm{BC}$ is the plant biomass of the control, and the subscripts of " $-\mathrm{Si}$ " and "+Si" are experimental treatment without and with $\mathrm{Si}$ application, respectively. For the studies without $\mathrm{Si}$ application to the control, the plant biomass increment was calculated using Eq. (2).

$\operatorname{PBI}(\%)=\frac{\mathrm{BS}_{+\mathrm{Si}_{i}-\mathrm{BS}_{-\mathrm{Si}}}}{\mathrm{BS}_{-\mathrm{Si}}} \times 100$

Besides, Si-mediated plant recovery from stressful conditions usually accompanies with increasing $\mathrm{Si}$ concentration and decreasing carbon concentration in plant biomass. Hence, plant biomass carbon increment (BCI) was calculated using Eq. (3).

$\mathrm{BCI}(\%)=\mathrm{PBI} \times \mathrm{DC}_{f}$

where $\mathrm{DC}_{f}$ is the coefficient of biomass carbon decreasing with $\mathrm{Si}$ accumulation in plant biomass. Until now, the largest $\mathrm{Si}$ content increase, which was induced by $\mathrm{Si}$ addition, was $3.96 \%$ by weight in rice leaf (Detmann et al. 2012). Thus, we concluded that $\mathrm{Si}$ application to alleviate multiple abiotic and biotic stresses increases no more than $4 \%$ of $\mathrm{Si}$ in plant biomass by weight. Besides, $1 \%$ of $\mathrm{Si}$ increase in plant biomass generally induces less than $1 \%$ plant biomass carbon reduction (Klotzbücher et al. 2018; Neu et al. 2017). Therefore, 0.96 was set as the coefficient in this study for estimating plant biomass carbon increment that is mediated by Si application under stressful conditions.

Similar to data calculation of plant biomass increment, crop yield increment (CYI) was calculated using Eq. (4) to exclude the Si fertilization effect.

$\mathrm{CYI}(\%)=\frac{\mathrm{YS}_{+\mathrm{Si}} / \mathrm{YS}_{-\mathrm{Si}}-\mathrm{YC}_{+\mathrm{Si}} / \mathrm{YC}_{-\mathrm{Si}}}{\mathrm{YC}_{+\mathrm{Si}} / \mathrm{YC}_{-\mathrm{Si}}} \times 100$ 
where YS is the crop yield under stressful condition, BC is the crop yield of the control, and the subscripts of "- $\mathrm{Si}$ " and " $+\mathrm{Si}$ " are experimental treatment without and with $\mathrm{Si}$ application, respectively. For the studies without Si application to the control, the crop yield increment was calculated using Eq. (5).

$\mathrm{CYI}(\%)=\frac{\mathrm{YS}_{+} \mathrm{Si}_{-}-\mathrm{YS}_{-\mathrm{Si}}}{\mathrm{YS}_{-\mathrm{Si}}} \times 100$

\subsection{Data analysis}

All statistical analyses were performed using SPSS software (IBM, version 23.0). Graph was drawn using Origin Software (OriginLab Corp., Version 9.0).

\section{Plant biomass carbon accumulation under abiotic and biotic stresses}

\subsection{Abiotic stresses}

Plants suffer from physiological stresses when exposed to abnormal environments such as extreme temperatures, drought, high salinity, heavy metals, and nutrient imbalance (Genga et al. 2011; Savvides et al. 2016). Hyperosmotic stress, cell dehydration, reactive oxygen species (ROS) overproduction, and leaf chlorosis are the main responses to such stresses (Table 1). In addition, plants endure secondary stresses when several abiotic stresses interplay. For example, interconnections between drought stress and salt stress may lead to nutritional deficiency and hyperosmotic stress, while $\mathrm{Ca}, \mathrm{B}$, $\mathrm{Zn}$, and $\mathrm{K}$ deficiencies often increase the incidences of plant disease and insect attack (Huber et al. 2012; Zhu and Gong 2014). By contrast, low $N$ availability caused by drought and salt stresses may enhance plant resistance to pest attacks (Huber et al. 2012). Plants have developed highly complicated strategies to efficiently acclimatize themselves to the adverse conditions (Zhu 2016). Network relationships between biological damages and abiotic stresses indicate that systemic acquired resistance of plants can alleviate most abiotic and biotic stresses.

Although plants can mediate the intrinsic defense networks to mitigate the damages caused by adverse habitats, most of them have to pay a tradeoff between extra-consumption of resources for homeostasis and plant growth. Equal proportions of plant biomass and biomass carbon are lost from abiotic stresses compared with non-stressful conditions due to almost the same carbon concentration of the harvested dry matter under stressful and non-stressful conditions. Pot experiments show that the biomass of maize (Zea mays) and broomcorn (Sorghum bicolor) decreased by 49 and $79 \%$ under drought stress, respectively (Hattori et al. 2005; Kaya et al. 2006). The biomass of pea (Pisum sativum) decreased by $38 \%$ under $100 \mu \mathrm{M}$ chromium (VI) stresses, as compared to biomass reduction of 5 and $64 \%$ in wheat (Triticum aestivum) seedling exposed to 5 and $25 \mu \mathrm{M}$ cadmium stress, respectively, and that of 33\% under UV-B stress (Tripathi et al. 2015, 2017; Wu et al. 2016a). Additionally, abiotic stresses caused by extreme weather and climate may result in plant growth arrest and even death, resulting in inefficient carbon assimilation and ANPP in terrestrial ecosystems (Kogan et al. 2004; Craine et al. 2012). In summary, plant exposure to abiotic stresses usually reduces plant biomass and crop yield, resulting in plant biomass carbon loss.

\subsection{Biotic stresses}

Herbivory, pathogen, and pest attacks are the main biotic stresses that plants need to cope with during their lifecycles (Table 1). The major determinants of plant disease and pest incidences include plant species (Massey et al. 2007), habitat (Massey et al. 2007), nutrient status, and the degree of overlap between the susceptible growth stages of the host plants and the reactive pathogens and pests (Walters and Bingham 2007; Huber et al. 2012). The renovation of injured tissues of slowgrowing plant species is more costly in resource-limited environments than that of fast-growing plant species in resourcerich environments (Massey et al. 2007). Furthermore, the complexity of these responses is significantly affected by the extent and duration of biotic stresses (both acute and chronic) (Cramer et al. 2011), which leads to different impacts on plant growth and biomass carbon accumulation. In summary, the investment in defensive strategies among plant species to resist or tolerate these biotic stresses is usually associated with plant growth rates and their habitats.

Plant physiological responses often have double-edged effects when they are used to counteract various biotic stresses. For example, the bilateral functions of ROS induced by various environmental stresses not only cause damage to plants but also act as signaling transducer and cause programmed cell death in response to fungal attack (Schieber and Chandel 2014; Demidchik 2015; Lehmann et al. 2015). Furthermore, Si coupling with Mn accumulation in the infected region may lead to increased biosynthesis of phenolics and phytoalexins, which are catalyzed by Mn-containing enzymes (Huber et al. 2012). In addition, many facultative and obligate parasites may increase the risk of disease outbreak, especially when the concentrations of sugars and amino acids in the apoplasms of the leaves increase due to nutrient imbalances such as insufficient $\mathrm{Ca}, \mathrm{B}, \mathrm{Zn}$, and $\mathrm{K}$ and excess $\mathrm{N}$ (Walters and Bingham 2007; Huber et al. 2012). These results indicate that plant nutrient status plays an important role in counteracting the negative effects of biotic stresses on plant growth and biomass accumulation. 


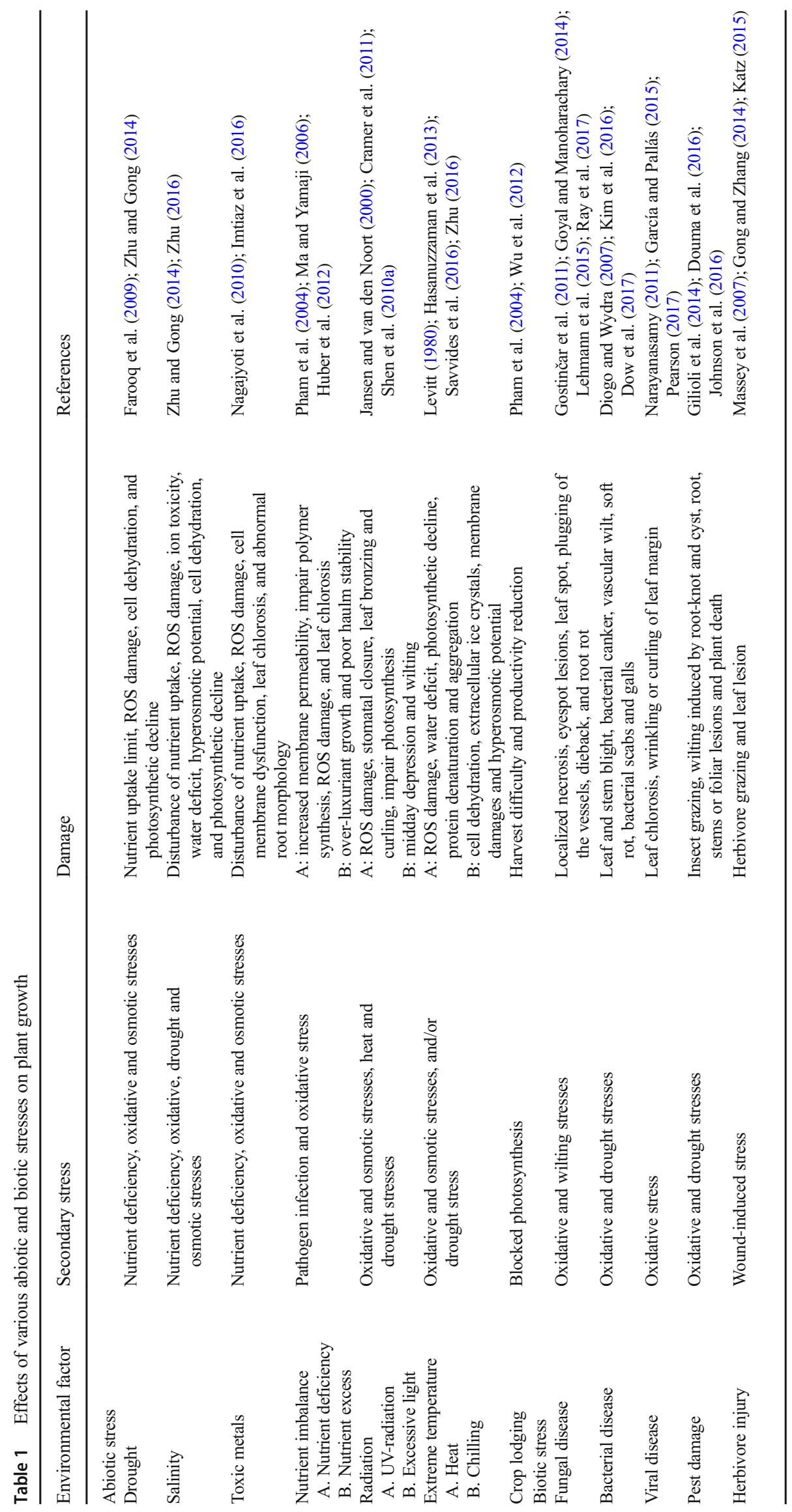


The effects of biotic stresses have two different patterns, i.e., pathogen infection and grazing, on suppression of plant growth and biomass accumulation (Table 1). Plants suffering from pathogen infection often undergo lower photosynthetic capacity and carbon assimilation due to leaf necrosis and vascular wilt. A pot experiment shows that rice (Oryza sativa) infected with leaf blight decreased by $55 \%$ of biomass on average (Song et al. 2016). In contrast, insect and herbivore grazing has an immediate biomass loss and the ANPP is regulated by the grazing intensity (Schönbach et al. 2010; Irisarri et al. 2016). In addition, extra-consumption of resources for systemic acquired resistance and homeostasis has negative effects on plant photosynthesis and carbon assimilation as well. In conclusion, plant biomass reduction caused by pathogen infection and herbivore damage usually generates potential loss of biomass carbon in terrestrial ecosystems.

\section{Silicon distribution in plants and its alleviation of stresses}

\subsection{Silicon distribution and accumulation in plants}

Silicon is the second most abundant element and constitutes $28.8 \%$ of the Earth's crust (Epstein 1999). The Si content in soils ranges widely from less than $1 \%$ in histosols to $45 \%$ in the very old podzols (Skjemstad et al. 1992; Sommer et al. 2006). In the soil matrix, primary silicate mineral, secondary clay mineral, and amorphous silica account for most of the total Si pool, but they are relatively insoluble and biogeochemically inert (Savant et al. 1997; Sommer et al. 2006). Plant-available $\mathrm{Si}$ is primarily released from the recycling of biogenic Si pools and partly derived from the geochemical cycling of mineral Si pools (Bartoli 1985; Alexandre et al. 1997; Tubaña and Heckman 2015; Cornelis and Delvaux 2016). In the plant-soil system, successive $\mathrm{Si}$ influx and efflux transporters in plants regulate $\mathrm{Si}$ uptake and transport from the solution in vitro to the terminals of the transpiration stream (Ma and Yamaji 2006). Monosilicic acid movement from soil solution to the exodermis and endodermis root cells passes through an influx channel-type transporter (Lsil) via the passive transport (Ma and Yamaji 2015). Then, an active Si efflux transporter (Lsi2) facilitates Si loading from the endodermis root cells to the xylem (Yamaji et al. 2015). In rice xylem sap, the concentration of monosilicic acid can reach up to $20 \mathrm{mM}$, while silicic acid in vitro polymerizes into silica gel when its concentration exceeds $2 \mathrm{mM}$ (Mitani et al. 2005). Monosilicic acid unloads from the xylem into leaf cells via another Si influx transporter ( $\mathrm{LsiO}$ ) as similar to Lsil, but its localization is in the xylem transfer cell layer (Ma and Yamaji 2015). In addition, another Si efflux transporter (Lsi3) localized at rice node in cooperation with Lsi2 and Lsi6 reloads $\mathrm{Si}$ to the xylem of diffuse vascular bundle and facilitates Si unloading to the panicle (Yamaji et al. 2015). Finally, more than $90 \%$ of $\mathrm{Si}$ in plants is distributed in the shoots and most of it is deposited in the leaf sheaths and leaf blades (Broadley et al. 2012). In summary, the ability of plants to absorb $\mathrm{Si}$ is regulated by the cooperative system of Si influx and efflux transporters in plant.

Increasing evidence suggested that the ability of Si accumulation in different plant species demonstrates a direct correlation between Si transporter genes (NIP2s) and Lsi2s (Deshmukh et al. 2015; Deshmukh and Bélanger 2016; Vivancos et al. 2016). However, homologous genes of Si transporters in different plant species do not show the same Si uptake and transport patterns due to diverse root and shoot architectures (Deshmukh and Bélanger 2016). In principle, all monocots (e.g., sugarcane, rice, and most cereals) and a few dicots (e.g., sunflower, soybean, and cucumber) are defined as high Si-accumulating plants ( $>1 \%$ dry weight) and acquire positive effects from Si application (Ma et al. 2001; Liang et al. 2005a; Deshmukh and Bélanger 2016). By contrast, most dicots (e.g., tomato) taking up small amounts of $\mathrm{Si}(<$ $0.1 \%$ dry weight) are defined as low Si-accumulating plants. The dicots accumulating $\mathrm{Si}$ ranging from 0.1 to $1 \%$ of $\mathrm{Si}$ belong to the intermediate $\mathrm{Si}$ accumulator category (Guntzer et al. 2012; Deshmukh and Bélanger 2016). In addition, systematical benefits of Si conferred to plants depend on the ability of Si adsorption among different plant species (Ma and Yamaji 2006; Deshmukh and Bélanger 2016). Hence, Siaccumulating plants are more sensitive to Si feeding than intermediate and low Si-accumulating plants.

\subsection{Silicon alleviation of abiotic stresses}

Silicon in the soil solution is transported to the rhizosphere as monosilicic acid $\left(\mathrm{H}_{4} \mathrm{SiO}_{4}\right)$ by belowground transpiration streams. Soluble Fe/Al-O-Si complexes may also be transferred to the root zones and activated by root exudates (Pokrovski et al. 2003; Hobara et al. 2016; Wu et al. 2016b). The accumulation of monosilicic acid in the rhizosphere and the formation of iron plaques on the root absorbency area play important roles in preventing the entrance of heavy metals into plant roots (Liang et al. 2005b; Wu et al. 2016b). Coprecipitation of toxic cationic metals with plant-available $\mathrm{Si}$ and adsorption of toxic anionic metals on the iron plaques are the major mechanisms for Si to mediate the alleviation of heavy metal toxicity in soils (Liang et al. 2005b; Gu et al. 2011; Adrees et al. 2015; Wu et al. 2016b). In addition, Si deposition in the roots is the primary inhibitory effect on apolasmic transport of $\mathrm{Na}^{+}$across the roots (Gong et al. 2006), while monosilicic acid competition with arsenite can reduce plant arsenic uptake under anaerobic conditions (Ma et al. 2008; Tripathi et al. 2013; Marmiroli et al. 2014; Tripathi et al. 2016a). Furthermore, Si-mediated alleviation of heavy metal toxicity also occurs in root cells and xylem vessels 


\section{Modulate ionic and osmotic homeostasis}

1. Prevent toxic ions uptake or transport from roots to shoots

2. Enhance tonoplast antiporter activities to compart toxic ions into vacuoles

3. Counteract plant transpiration and tissue sap liquidity

4. Modulate ion uptake and distribution with the plant

$\checkmark$ Enhance salt stress tolerance

$\checkmark$ Elevate drought stress tolerance

$\checkmark$ Dry taste to insect and herbivore

$\checkmark$ Alleviate metal ions toxic effects

$\checkmark$ Increase the resistance to nutritional deficiency-induced diseases and pests

\section{Silica cell/bodies and phenolic compounds}

1. Rough taste to insect and herbivore

$\checkmark$ Reduce risks of insect attack and herbivore grazing

Crosslink with pectins or polyphenols in plant cell wall

1. Stretch Leaf blade

2. Improve haulm tenacity

$\checkmark$ Promote photosynthetic efficiency

$\checkmark$ Decrease lodging susceptibility

Si-cuticle double layer

1. Physical barrier hampering pathogen penetration

2. Decrease transpiration

$\checkmark$ Improve water use efficiency

$\checkmark$ Enhance drought stress tolerance

$\checkmark$ Cement saline stress tolerance

\section{Co-precipitation and adsorption in root zone}

1. Cation such as $\mathrm{Cd}^{2+}$ and $\mathrm{Cu}^{2+}$ co-precipitate with $\mathrm{Si}(\mathrm{OH})_{4}$

2. Anion such as $\mathrm{AsO}_{3}{ }^{3-}$ can be adsorbed on iron plaque

$\checkmark$ Alleviate metal toxicities

Modulate toxic ions uptake

$\mathrm{Si}(\mathrm{OH})$

Fig. 2. Principal mechanisms of silicon-mediated alleviation of abiotic and biotic stresses on plant growth and development

(Liang et al. 2007; Lukačová et al. 2013; Ma et al. 2014). The activated $\mathrm{Si}$ in the rhizosphere, root systems, and xylem vessels inactivates the detrimental substances in vitro and in vivo (Fig. 2) and prevents them from entering plant shoots. For nutrient uptake, Si application elevates the harvest index and nitrogen use efficiency (Detmann et al. 2012; Song et al. 2017). More plant-available Si can suppress excessive phosphorus uptake in rice (Ma and Takahashi 1990) but promote phosphorus uptake under phosphorus deficiency stress (Ma et al. 2001; Pontigo et al. 2015; Kostic et al. 2017). Increasing Si application can mediate potassium accumulation in shoots when plants are subject to salt stress and potassium deficiency (Wang and Han 2007; Chen et al. 2015). In addition, Si can alleviate iron deficiency in cucumber (Cucumis sativus) and soybean (Glycine max), although this effect is plant-specific and dosedependent (Gonzalo et al. 2013; Pavlovic et al. 2013). However, the effects of Si on manganese and zinc are not clear (Hernandez-Apaolaza 2014). In general, Si imposes positive effects on regulation of plant nutrition uptake.

Considerable amounts of $\mathrm{Si}$ that are deposited in the cell walls of plant roots and xylem vessels can withstand crop lodging through strengthening the mechanical property of plant roots and the haulms (Balasta et al. 1989; Hattori et al. 2003; Ma and Yamaji 2006). More than 90\% Si absorbed by plant roots is transferred into shoots via the xylem (Ma and Takahashi 2002). High concentrations of monosilicic acid in the xylem and leaves can improve the osmotic potential of epidermis cells and increase the leaf water potential against plant evapotranspiration (Mitani et al. 2005; Pei et al. 2010;
Chen et al. 2011; Ming et al. 2012). Silicon deposition beneath the cuticle of the epidermal cells and the inflorescence bracts reduces the leaf and panicle transpiration, stretches the leaf blade, and promotes photosynthetic efficiency (Hattori et al. 2008; Ma and Yamaji 2006, 2008; Tripathi et al. 2016b). Overall, these beneficial effects of Si on plant water retention have been shown to improve plant tolerance to drought, salt, extreme temperature, and excessive light stresses (Kaya et al. 2006; Liang et al. 2008; Ming et al. 2012; Tuna et al. 2008; Soundararajan et al. 2014; Shen et al. 2010a; Guntzer et al. 2012; Zhu and Gong 2014) (Fig. 2). In addition, Si application can improve plant water use efficiency and increase photosynthesis pigment as well as net assimilation rate under multiple abiotic stresses (Shen et al. 2010b; Chen et al. 2011; Shi et al. 2013). In summary, Si-mediated changes to osmotic potential and the physical barrier can help regulate plant transpiration and improve water use efficiency.

The alleviation of oxidative stress caused by silicon accumulation in plants (Shen et al. 2010a; Zhu et al. 2016) may decrease the activity of ROS-scavenging enzymes that are involved in lignin, phenolics, and phytoalexin biosynthesis (Ortega et al. 2006; Huber et al. 2012; Schaller et al. 2012). For example, lignin content in canola decreases when $\mathrm{Si}$ is applied as a fertilizer and increases as $\mathrm{Si}$ is deficient (Hashemi et al. 2010; Suzuki et al. 2012; Zhang et al. 2013s). Application of Si can decrease the concentrations of malondialdehyde (MDA) and hydrogen peroxide $\left(\mathrm{H}_{2} \mathrm{O}_{2}\right)$ without complete relation to goal-oriented ROS-scavenging enzyme activities (Shen et al. 2010a; Zhang et al. 2013; 
Fig. 3. Possible pathways of Simediated alleviation of phytohormone defense systems and antioxidant defense systems. SA, salicylic acid; JA, jasmonic acid; ET, ethylene; ABA, abscisic acid. The figure depicts that the stress hormone response and antioxidant system may be regulated by post-feedback of $\mathrm{Si}$ mediated alleviation rather than forward feedback of Si-associated signaling pathway

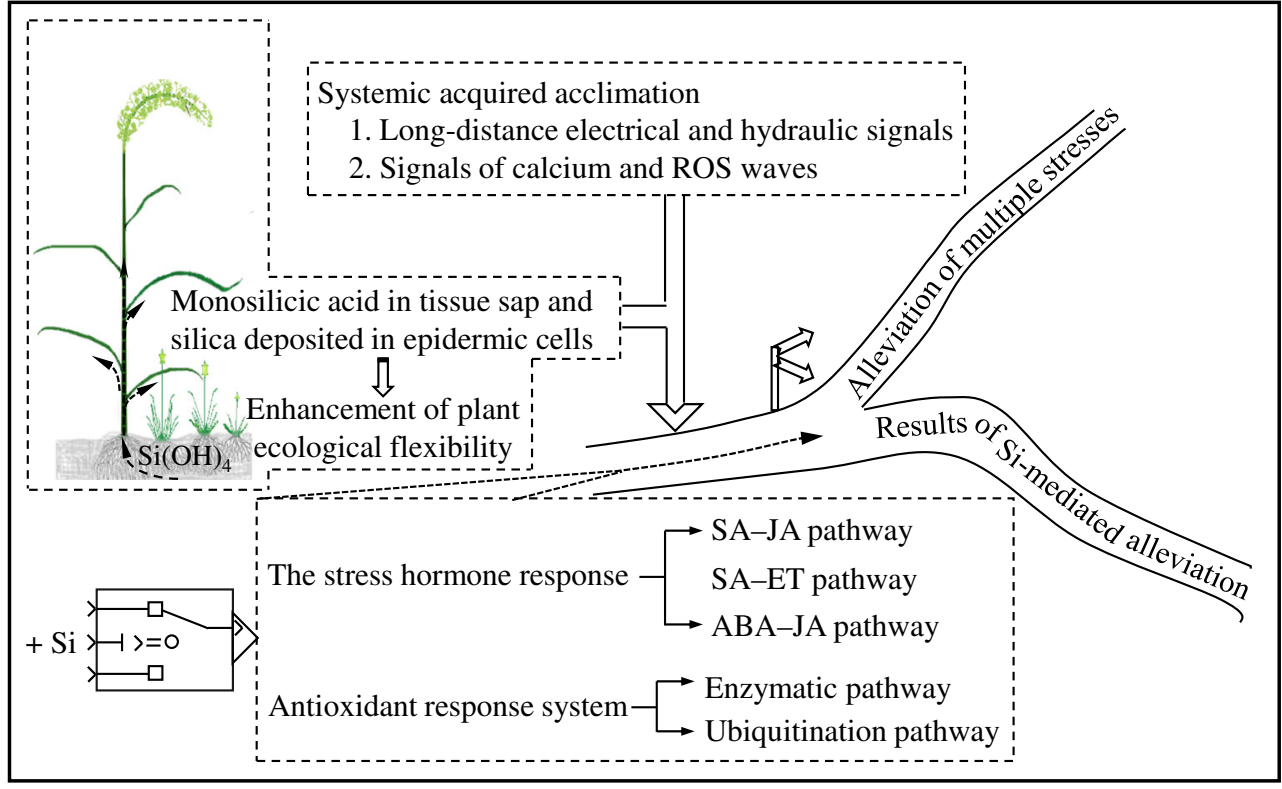

Coskun et al. 2016), indicating indirect effects of Si on biosynthesis of antioxidant enzyme (Fig. 3). Hence, we speculate that $\mathrm{Si}$ accumulation in plants promotes tolerance of plants to the adverse effect of various abiotic stresses, which decreases the effects of oxidative stress as well as ROS production and reduces ROS-dependent signal transduction as well as biosynthesis of antioxidant enzyme (Schieber and Chandel 2014; Zhu et al. 2016). Furthermore, based on systemic-acquired acclimation, we also suggest that the effects of Si-mediated alleviation of the archetypal defense hormones can be derived from the improvement of physiological conditions rather than from the regulation of $\mathrm{Si}$ on the pathways of plant hormones (Kim et al. 2014; Rizwan et al. 2015) (Fig. 3). Until now, no direct evidence has shown the existence of Si-involved signaling pathway in plants. Therefore, antioxidant enzyme activities and phytohormone levels independent of Si concentration are probably the result of Si-mediated alleviation instead of $\mathrm{Si}$ itself. In conclusion, the down-regulated responses of antioxidant defenses and hormone immunity are probably attributed to Si-mediated improvements in plant homeostasis.

\subsection{Silicon regulation of biotic stresses}

The deposition of $\mathrm{Si}$ in the cell walls of roots improves the biomechanical properties of plants (Hansen et al. 1976) and thus increases root resistance to soil-borne diseases and pests (Johnson et al. 2010). The appearance of root-specific phytoliths in the roots and tubers shows that Si also participates in protecting belowground tissues from soil-borne pests (Lux et al. 2003; Chandler-Ezell et al. 2006). Plant transpiration leads to the accumulation of over $90 \% \mathrm{Si}$ in the shoots where the $\mathrm{Si}$ is used as the structural materials for the cuticlesilica double layer and silicified cells (Hodson and Sangster
1989; Ma and Takahashi 2002; Huber et al. 2012). The cuticle-silica double layer often serves as a physical barrier that impedes the penetration of fungus and pest (Ma and Yamaji 2006). Silica cell/bodies in grasses can result in rough taste to insect pests and herbivores (Hartley and DeGabriel 2016) (Fig. 2). Furthermore, it is the symplastic Si, rather than the apoplastic Si, that seems to inhibit the spread of Pythium aphanidermatum in tomato plant roots (Heine et al. 2007). The osmotic effect of soluble Si (Liang et al. 2005c; Liang et al. 2015) and the Si-associated biosynthesis of phytoalexins (Ghanmi et al. 2004) enhance the resistance of host plants to pathogen infection. This may be related to the symplastic Si (Fig. 3), which may act as a modulator that influences the timing and extension of the systemic acquired resistance (Liang et al. 2015) through the long-distance electrical and hydraulic signals. However, the interaction between the symplastic $\mathrm{Si}$ and systemic acquired resistance is not clear. The effects of Si-mediated plant osmotic and water potential on electrical and hydraulic signals under biotic stresses need to be further investigated.

Silicon accumulated around the attempted infection sites is three to four times higher than that around the successful penetration sites (Heath and Stumpf 1986; Carver et al. 1987). Manganese accumulation that accompanies Si at the infection sites may be related to Si-mediated biosynthesis of phenolics and phytoalexins to resist pathogen infection (Menzies et al. 1991; Huber et al. 2012). Furthermore, plant diseases and pests induced by nutrient deficiencies and ion imbalances would be alleviated by Si-mediated nutrient uptake and distribution (Pavlovic et al. 2013; Gonzalo et al. 2013; HernandezApaolaza 2014; Chen et al. 2015). Therefore, Si accumulation in plant tissues may increase the resistance to nutrient deficiency-induced diseases and pests by alleviating 
micronutrient deficiencies in plants. Besides, the cuticle-silica double layer and silica cell/bodies do not account for all the preventive effects because soluble $\mathrm{Si}$ in plant tissues is also involved in prophylactic alleviation of the detrimental impact of many biotic stresses (Liang et al. 2015). These studies show that $\mathrm{Si}$ deposition in leaves and silica cell/bodies postpones protection from pathogen and insect pest attack, while soluble $\mathrm{Si}$ in plant tissues plays a real-time role in plant resistance.

Classic hormone defense pathways have little correlation with Si-mediated plant resistance to various biotic stresses (Van Bockhaven et al. 2015; Vivancos et al. 2015). The downregulated archetypal defense hormones such as abscisic acid, jasmonic acid, and salicylic acid are not derived from the $\mathrm{Si}$ mediated mechanism related to plant disease resistance (Van Bockhaven et al. 2015; Vivancos et al. 2015). At present, only the ethylene pathway of rice against the brown spot fungus has been testified (Van Bockhaven et al. 2015). Silicon-induced changes in plant enzymatic or non-enzymatic defense systems that counteract ROS overproduction (Debona et al. 2014; Nascimento et al. 2016) may also result from Si-mediated alleviation of various biotic stresses (Fig. 3). In summary, increasing $\mathrm{Si}$ in plant tissues could reduce the metabolic costs of systemic acquired acclimation for adapting to multiple biotic stresses.

\section{Silicon enhancement of plant biomass carbon accumulation under stresses}

\subsection{Silicon enhancement of carbon accumulation under abiotic stresses}

Silicon supply has beneficial effects on plant biomass carbon accumulation under multiple abiotic stresses (Hattori et al. 2005; Liang et al. 2005b; Fu et al. 2012; Mateos-Naranjo et al. 2015). Compared with plant biomass carbon loss caused by multiple abiotic stresses, Si-mediated plant biomass carbon recovery rarely reaches the biomass carbon accumulation under non-stress condition. Compared to the control, wheat plants lose their biomass carbon by 32 and $44 \%$ under salinity stress and 25 and $16 \%$ in salt-tolerant and salt-sensitive Si-fed plants, respectively (Tuna et al. 2008). The stress-sensitive plants would receive more biomass carbon accumulation than the stress-tolerant ones as well as when $\mathrm{Si}$ is added under drought stress and heavy metal toxicity (Kaya et al. 2006; Farooq et al. 2013; Wu et al. 2016a). In addition, increasing $\mathrm{Si}$ application (monosilicic acid in soil solution at $\mathrm{pH}$ below 9.0 is less than $2 \mathrm{mM}$ ) can improve the performance of plant biomass carbon accumulation (Kaya et al. 2006; Tuna et al. 2008; Pei et al. 2010). However, the performance of Si application to alleviate cadmium toxicity in wheat increases with stress severity in moderate stress conditions but decreases in both mild stress and severe stress conditions (Farooq et al.
2013; Wu et al. 2016a). The results suggest that Si-mediated biomass carbon accumulation probably displays progressive increase from mild to moderate stress but turns into declination under severe stress conditions. In summary, the recovery performances of plant biomass carbon induced by Simodulated mitigation have different responses to plant cultivars, $\mathrm{Si}$ application dosage, and abiotic stress intensity. Therefore, we propose that the efficiency of Si-mediated alleviation responses to the severity gradients of abiotic stresses will probably display a bell-shaped curve (Fig. 4(a)). Accordingly, the input-output ratio between Si fertilization and the restoration performance of plant biomass carbon should be fully scrutinized.

In addition, most studies have reported that $\mathrm{Si}$ application to alleviate many abiotic stresses can enhance the expression of key genes related to photosynthesis, increase photosynthetic pigments, and promote plant photosynthesis as well as net assimilation rate (Shen et al. 2010b; Chen et al. 2011; Shi et al. 2013; Song et al. 2014; Li et al. 2015a; Kang et al. 2016). As a result, Si-mediated recovery from multiple abiotic stresses can stimulate $\mathrm{CO}_{2}$ assimilation in plants and biomass carbon accumulation in terrestrial ecosystems. Furthermore, Si application to grassland can enhance ANPP and maintain biodiversity of grassland under high nitrogen fertilizer (Xu et al. 2015). Specifically, the mass proportion of the increased Si ranges from 0.02 to $3.96 \%$ of the recovered plant biomass (Detmann et al. 2012; Kurabachew and Wydra 2014), while $1 \%$ of $\mathrm{Si}$ increase in rice and wheat reduces plant biomass carbon by 0.87 and $0.57 \%$, respectively (Klotzbücher et al. 2018; Neu et al. 2017). It suggests that an increase in the Si content of plant by $1 \%$ may reduce the plant biomass carbon by less than $1 \%$. Therefore, although carbon concentration of plant biomass decreases with silicon accumulation, more than $96 \%$ of the recovered plant biomass contributes to plant biomass carbon accumulation. In conclusion, Si cycling improves carbon accumulation through abiotic stress mitigation in terrestrial ecosystems.

\subsection{Silicon enhancement of carbon accumulation under biotic stresses}

Plant growth and biomass accumulation often respond differently to herbivores, insect pests, and diseases due to multifarious attack patterns (Table 1). Therefore, the response mechanisms of Si-modulated alleviation may depend on the biotic stresses the plant is subject to (Etesami and Jeong 2018). Silicon-modulated prevention of biotic stresses is the major effect of Si-associated ecological functions (Soininen et al. 2013; Hartley and DeGabriel 2016). The effect of Si-mediated alleviation on various biotic stresses, especially on the diseases induced by fungi and bacteria, often depends on their active periods and the susceptible stages of the host plants (Huber et al. 2012). 


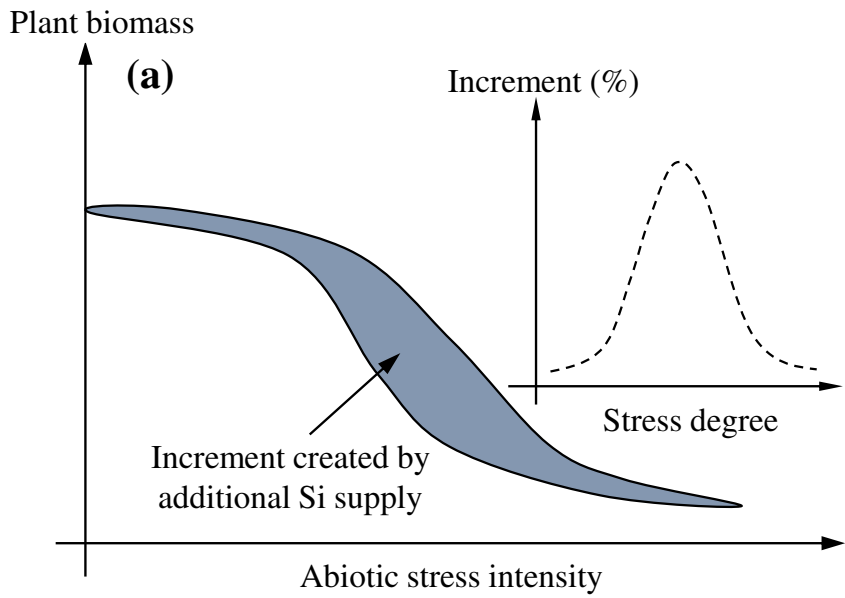

Fig. 4. Potential of plant biomass enhanced by additional silicon supply under different abiotic (a) and biotic (b) stress degrees. The hypotheses we proposed illustrate that the performances of plant biomass recovery

Compared to the control, Song et al. (2016) reported that rice biomass decreased by 59 and $72 \%$ under bacterial blight infection (Xanthomonas oryzae pv. oryzae) without $\mathrm{Si}$ addition in hydroponic and pot experiments, respectively, but decreased by 55 and $47 \%$ due to Si application. In addition, Si-mediated plant biomass carbon recovery from biotic stresses demonstrated a positive correlation with the application amount of Si (Ferreira et al. 2015). Similar to abiotic stresses, more than $96 \%$ of the Simediated plant biomass recovery under biotic stresses contributes to plant biomass carbon. However, the

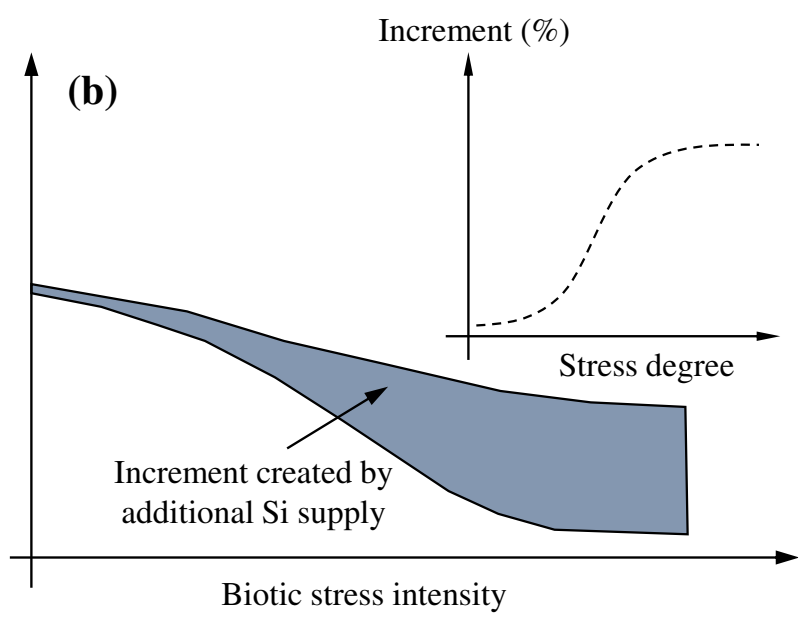

from Si-mediated alleviation are stress degree-dependent for abiotic stress and stress degree-independent for biotic stress

mutability of biomass carbon loss which is caused by different biotic stresses often gives rise to difficulties in evaluating Si-mediated alleviation efficiency.

Plant species with different survival strategies and habitats also have a decisive influence on the efficiency of Simediated alleviation of plant biomass losses (Massey et al. 2007; Kurabachew and Wydra 2014). For example, chewing insects and herbivores have few adverse effects on inherently fast-growing plant species that live in resource-rich environments, whereas they have considerable negative impacts on slow-growing plant species that
Fig. 5. Frequency distributions of Si-mediated plant biomass carbon restoration from abiotic and biotic stresses. Data were collected from peer-reviewed publications. Plant biomass carbon increment was calculated from Si-mediated plant biomass increment coupling with the coefficient of 0.96 , which was estimated from the tradeoff of Simediated plant $\mathrm{Si}$ accumulation and biomass carbon loss in plant biomass

\section{Relative Frequency}

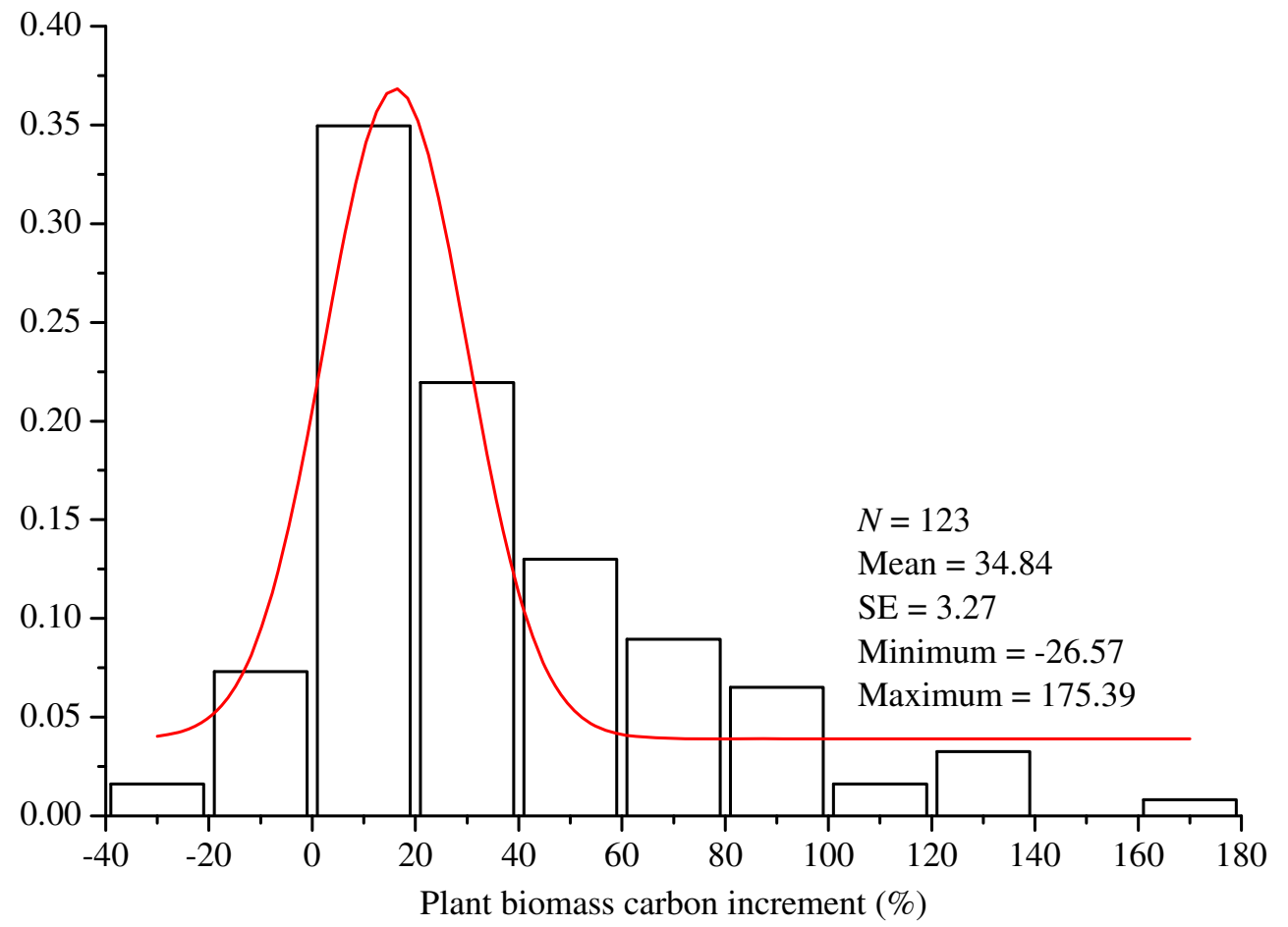


Table 2 Silicon enhancement of the estimated plant biomass carbon accumulation under abiotic and biotic stresses

\begin{tabular}{|c|c|c|c|}
\hline Stress type & Plant species & $\begin{array}{l}\text { Estimated biomass } \\
\text { carbon increment }(\%)\end{array}$ & References \\
\hline \multirow[t]{12}{*}{ Drought } & Sorghum bicolor & $98-123$ & Hattori et al. (2005) \\
\hline & Zea mays & $26-43$ & Kaya et al. (2006) \\
\hline & Triticum aestivum & -1 to 12 & Ahmad et al. (2007) \\
\hline & Chloris gayana & 88 & Eneji et al. (2008) \\
\hline & Sorghum sudanense & 18 & \\
\hline & Festuca arundinacea & 28 & \\
\hline & Phleum pratense & 44 & \\
\hline & Triticum aestivum & 48 & Pei et al. (2010) \\
\hline & Lupinus albus & $37-63$ & Abdalla (2011) \\
\hline & Sorghum bicolor & 26 & Ahmed et al. (2011) \\
\hline & Oryza sativa & $57-60$ & Chen et al. (2011) \\
\hline & Oryza sativa & 17 & Ming et al. (2012) \\
\hline \multirow[t]{9}{*}{ Salt } & Solanum lycopersicum & 21 & Al-Aghabary et al. (2005) \\
\hline & Triticum aestivum & $5-49$ & Tuna et al. (2008) \\
\hline & Triticum aestivum & $26-116$ & Ali et al. (2009) \\
\hline & Cucurbita pepo & -2 to 35 & Savvas et al. (2009) \\
\hline & Saccharum officinarum & $5-83$ & Ashraf et al. (2010) \\
\hline & Oryza sativa & $16-39$ & Shi et al. (2013) \\
\hline & Abelmoschus Medicus & $4-15$ & Abbas et al. (2015) \\
\hline & Solanum lycopersicum & 75 & Li et al. $(2015 b)$ \\
\hline & Cicer arietinum & $6-29$ & Garg and Bhandari (2016) \\
\hline \multirow[t]{4}{*}{ UV-B radiation } & Saccharum officinarum & $6-12$ & Elawad et al. (1985) \\
\hline & Glycine max & $4-10$ & Shen et al. (2010b) \\
\hline & Triticum aestivum & 53 & Pavlovic et al. (2013) \\
\hline & Triticum aestivum & -13 to -1 & Tripathi et al. (2017) \\
\hline P deficiency & Oryza sativa & $4-16$ & Ma et al. (2001) \\
\hline Fe deficiency & Glycine max & -3 to 45 & Gonzalo et al. (2013) \\
\hline $\mathrm{Fe}^{2+}$ toxicity & Oryza sativa & $8-17$ & Fu et al. (2012) \\
\hline $\mathrm{Cu}$ toxicity & Spartina densiflora & 42 & Mateos-Naranjo et al. (2015) \\
\hline Zn toxicity & Glycine $\max$ & $26-40$ & Pascual et al. (2016) \\
\hline \multirow[t]{2}{*}{ As toxicity } & Oryza sativa & -21 to 33 & Wu et al. (2016b) \\
\hline & Oryza sativa & -27 to 9 & Zia et al. (2017) \\
\hline \multirow[t]{5}{*}{ Cd toxicity } & Zea mays & $60-123$ & Liang et al. (2005b) \\
\hline & Gossypium hirsutum & $25-44$ & Farooq et al. (2013) \\
\hline & Avicennia marina & $4-11$ & Zhang et al. (2014) \\
\hline & Triticum aestivum & $8-40$ & Wu et al. (2016a) \\
\hline & Solanum nigrum & 5 & Liu et al. (2013) \\
\hline \multirow[t]{2}{*}{ Cr toxicity } & Hordeum vulgare & $39-59$ & Ali et al. (2013) \\
\hline & Pisum sativum & 9 & Tripathi et al. (2015) \\
\hline Mn toxicity & Cucurbita moschata & $81-137$ & Ma et al. (2001) \\
\hline Bacterial blight & Oryza sativa & $5-87$ & Song et al. (2016) \\
\hline Bacterial fruit blotch & Cucumis melo & $29-175$ & Ferreira et al. (2015) \\
\hline \multirow[t]{2}{*}{ Bacterial wilt } & Solanum lycopersicum & 42 & Diogo and Wydra (2007) \\
\hline & Solanum lycopersicum & $15-66$ & Kurabachew and Wydra (2014) \\
\hline Brown spot & Oryza sativa & $70-100$ & Ning et al. (2014) \\
\hline
\end{tabular}

live in resource-poor environments (Massey et al. 2007). Therefore, the Si-mediated alleviation of different plant species living in different habitats could lead to variations in recovery performances. Nevertheless, positive impacts have been demonstrated in crops and grasses, especially for high Si-accumulating crops (Datnoff et al. 1997; Ma and Takahashi 2002) and grasses grown in poor-resource habitats (Massey et al. 2007; Soininen et al. 2013; Hartley and DeGabriel 2016). Accordingly, we propose a hypothesis that the efficiency of Si-mediated alleviation against the severity of a certain biotic stress follows an S-shaped curve (Fig. 4(b)). The beneficial effects of the Simodulated restoration would increase with Si supply and the severity of the biotic stresses. The relatively earlier formation of the cuticle-silica double layer and silica cells/bodies will improve resistance to biotic stresses during the highest active period of pathogens and pests. As a result, the beneficial effects of $\mathrm{Si}$ on plant biomass recovery from multiple biotic stresses will enhance plant biomass carbon accumulation in terrestrial ecosystems. 
Table 3 Silicon enhancement of crop yield under abiotic and biotic stresses

\begin{tabular}{llll}
\hline Stress type & Plant species & $\begin{array}{l}\text { Range of yield } \\
\text { increment (\%) }\end{array}$ & References \\
\hline Drought stress & Triticum aestivum & $14-25$ & Ahmed et al. (2016) \\
& Vitis vinifera & $11-17$ & Zhang et al. (2017) \\
Salt stress & Cucurbita pepo & $1-26$ & Savvas et al. (2009) \\
& Vicia faba & -6 to 48 & Kardoni et al. (2013) \\
P deficiency & Oryza sativa & $20-55$ & Ma et al. (2001) \\
As toxicity & Oryza sativa & -17 to 60 & Wu et al. (2016b) \\
Fungal infection & Phaseolus vulgaris & 13 & Polanco et al. (2014) \\
Neck blast & Oryza sativa & $18-73$ & Seebold et al. (2000) \\
& Oryza sativa & $33-51$ & Datnoff and Rodrigues (2005) \\
Stalk borer damage & Saccharum officinarum & $4-23$ & Keeping and Meyer (2002) \\
\hline
\end{tabular}

\section{Implications for the management of terrestrial ecosystems}

In terrestrial ecosystems, biogenic Si dissolution and mineral weathering are the major sources of bio-available Si pools (Tubaña and Heckman 2015; Cornelis and Delvaux 2016). The supplement rate of monosilicic acid to soil solution depends mainly on the size of bio-available Si pools, water retention time, temperature, and Si turnover rate (Sommer et al. 2006; Liang et al. 2015; Tubaña and Heckman 2015; Cornelis and Delvaux 2016). Rapidly available Si in soils and watersoluble $\mathrm{Si}$ in rivers have been used to estimate the biogeochemical cycles of Si in many watersheds (Neal et al. 2005; Klotzbücher et al. 2015), while little attention has been given to the Si pool in terrestrial vegetation. However, the biogeochemical Si cycle in terrestrial ecosystems plays a considerable role in improving ANPP and ecosystem resilience (Massey et al. 2007; Tuna et al. 2008; Wu et al. 2016a). The multiple beneficial effects of $\mathrm{Si}$ on plant growth and biomass accumulation are more significant under various stresses (Ma
Fig. 6. Primary approaches of Simediated enhancement of ecosystem ANPPs and plant biomass carbon accumulation

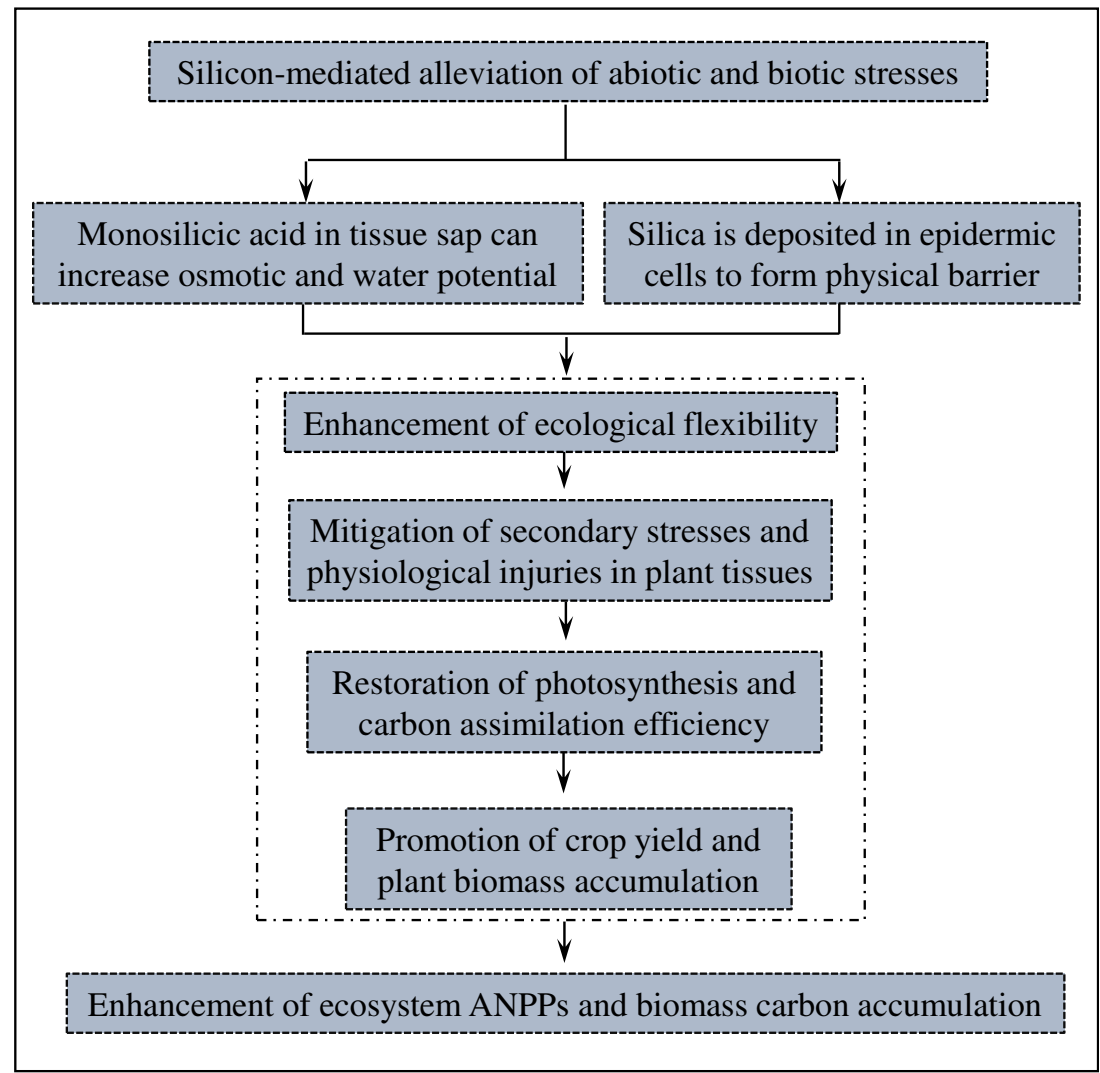


and Takahashi 2002). In total, Si-mediated plant biomass restoration from multiple abiotic and biotic stresses contributes, on average, to $35 \%$ of biomass carbon (Fig. 5, Table 2) and $24 \%$ of crop yield increments (Table 3 ). By contrast, the effect of Si-mediated restoration of plant biomass is ambiguous under arsenic stress (Wu et al. 2016b; Zia et al. 2017). In addition, the Si-mediated defensive responses commonly demonstrate a systemic acquired acclimation (Zhu 2016) and result in survival cost minimization. Overall, regardless of the plantavailable Si located in the rhizosphere, plant roots, xylem vessel, or leaves, the beneficial effects of $\mathrm{Si}$ on the alleviation of abiotic and biotic stresses play crucial roles in the performances of belowground and aboveground plant organs.

The restoration of plant biomass that is derived from Si-mediated alleviation of abiotic and biotic stresses would promote the ANPP of terrestrial vegetation and ecosystem carbon accumulation (Fig. 6). Different levels of $\mathrm{Si}$ application can change the contents of plant cellulose, lignin, and phenol that depend on plant tissue function (Schaller et al. 2012; Klotzbücher et al. 2018). In summary, the elevated ANPPs have positive effects on the long-term carbon sequestration in terrestrial ecosystem and soils. However, the concentration of $\mathrm{Si}$ in the shoots varies greatly among plant species (Ma and Takahashi 2002; Hodson et al. 2005), which suggests that $\mathrm{Si}$ requirement and the restoration effects will differ greatly among different plant species under the same abiotic or biotic stresses. Moreover, different defensive investment strategies among plant species against herbivore grazing (Massey et al. 2007) suggest that the efficiency of $\mathrm{Si}$ for different plant species to cope with various environmental stresses would also vary considerably. This means that the effects of $\mathrm{Si}$ on plant biomass carbon accumulation are very difficult to evaluate across many ecosystems but relatively easy for croplands and grasslands due to their fewer plant species and higher sensitivity to environmental changes. Therefore, the distribution of vegetation and the supply capacity of plant-available $\mathrm{Si}$ are the main determinants to evaluate the utility of $\mathrm{Si}$ to ecosystem resilience.

Terrestrial ecosystems in fragmented landscapes or resource-imbalanced regions constantly suffer from multiple abiotic and biotic stresses (Walters and Bingham 2007; Renton et al. 2013). The interconnection among the primary and secondary stresses greatly decreases plant biomass production and local biodiversity, which results in ecosystem degradation (Eneji et al. 2008; Cramer et al. 2011; Rasool et al. 2013). Because Si has versatile and beneficial effects on plant growth under multiple abiotic and biotic stresses (Liang et al. 2007; Ma and Yamaji 2008; Farooq and Dietz 2015; Meharg and Meharg 2015), more plant-available Si supply to these vulnerable landscapes could enhance the ecosystem health and resilience and thus promote the ecological restoration. Overall, ecosystems that possess more bioavailable Si would have a higher ANPP (Fig. 6), which could be crucial for terrestrial carbon turnover and result in more ecosystem carbon accumulation, especially under abiotic and/or biotic stresses.

\section{Conclusions and perspectives}

Based on the adverse impacts of multiple stresses on plant growth and the mechanisms of Si-mediated alleviation under abiotic and biotic stresses, this review highlighted the role of Si in enhancing plant biomass carbon accumulation. More plant-available $\mathrm{Si}$ in the ecosystem can enhance the ANPP and plant biomass carbon accumulation under various stress conditions. It is presumed that $\mathrm{Si}$-mediated recovery of plant biomass usually exhibits a bell-shaped response curve to abiotic stresses and an S-shaped response curve to biotic stresses. Although more Si accumulation in plant reduces carbon concentration of plant biomass, more than $96 \%$ of the increased plant biomass contributes to plant biomass carbon accumulation. Si application to crops suffering from abiotic and biotic stresses can increase averaged plant biomass carbon and crop yield by 35 and 24\%, respectively. However, the effectiveness of Si-mediated restoration significantly fluctuates with plant species and cultivars, intensity of abiotic and biotic stresses, and bio-available Si supply. Silicon-mediated alleviation usually exhibits immediate and preventive effects on plants suffering from abiotic and biotic stresses. In brief, additional Si supply and the subsequent increase in biogeochemical Si cycle could alleviate the adverse effects of abiotic and biotic stresses and thus accelerate biomass carbon accumulation in terrestrial ecosystems.

Based on this review, we suggest that researchers should investigate further the following areas:

1. Because experiments on $\mathrm{Si}$ application have yet mainly been conducted in hydroponics and pots, field- to ecosystem-scale studies are now urgently needed.

2. Several challenges, such as the coupling relations between $\mathrm{Si}$ and plant essential elements, the efficiencies of Si-mediated plant biomass carbon restoration among plant species and stress intensities, and the relationship between biogeochemical $\mathrm{Si}$ cycle and the resilience of terrestrial ecosystems, require further investigation especially in the fragmented landscapes.

3. Finally, it should be developed an evaluation model that predicts Si-mediated recovery contribution to plant biomass carbon accumulation in different terrestrial ecosystems. 
Funding information We acknowledge the support from the National Natural Science Foundation of China (Approval Nos. 41522207, 41571130042, 31572191,and 31772387) and the State's Key Project of Research and Development Plan of China (2016YFA0601002).

\section{References}

Adrees M, Ali S, Rizwan M, Rehman MZ, Ibrahim M, Abbas F, Farid M, Qayyum MF, Irshad MK (2015) Mechanisms of silicon-mediated alleviation of heavy metal toxicity in plants: a review. Ecotoxicol Environ Saf 119:186-197. https://doi.org/10.1016/j.ecoenv.2015. 05.011

Alexandre A, M eunier JD, Colin F, Koud JM (1997) Plant impact on the biogeochemical cycle of silicon and related weathering processes. Geochim Cosmochim Acta 61:677-682. https://doi.org/10.1016/ S0016-7037(97)00001-X

Balasta MLFC, Perez CM, Juliano BO, Villareal CP, Lott JNA, Roxas DB (1989) Effects of silica level on some properties of Oryza sativa straw and hull. Can J Bot 67:2356-2363. https://doi.org/10.1139/ b89-301

Bartoli F (1985) Crystallochemistry and surface properties of biogenic opal. Eur J Soil Sci 36:335-350. https://doi.org/10.1111/j.13652389.1985.tb00340.x

Broadley M, Brown P, Cakmak I, Ma JF, Rengel Z, Zhao FJ (2012) Beneficial elements. In: Marschner P (ed) Marschner's mineral nutrition of higher plants, 3rd edn. Science Press, Beijing, pp 249-269. https://doi.org/10.1016/B978-0-12-384905-2.00008-X

Carver TLW, Zeyen RJ, Ahlstrand GG (1987) The relationship between insoluble silicon and success or failure of attempted primary penetration by powdery mildew (Erysiphe graminis) germiling on barley. Physiol Mol Plant P 31:133-148. https://doi.org/10.1016/08855765(87)90012-9

Casey WH, Kinrade SD, Knight CTG, Rains DW, Epstein E (2004) Aqueous silicate complexes in wheat, Triticum aestivum L. Plant Cell Environ 27:51-54. https://doi.org/10.1046/j.0016-8025.2003. 01124.x

Chandler-Ezell K, Pearsall DM, Zeidler JA (2006) Root and tuber phytoliths and starch grains document manioc (Manihot esculenta) arrowroot (Maranta arundinacea), and lleren (Calathea sp.) at the Real Alto site, Ecuador. Econ Bot 60:103-120. https://doi.org/ 10.1663/0013-0001(2006)60 [103:RATPAS]2.0.CO;2

Chen DQ, Cao BB, Wang SW, Liu P, Deng XP, Yin LN, Zhang SQ (2015) Silicon moderated the K deficiency by improving the plantwater status in sorghum. Sci Rep 6:22882. https://doi.org/10.1038/ srep22882

Chen W, Yao XQ, Cai KZ, Chen JN (2011) Silicon alleviates drought stress of rice plants by improving plant water status, photosynthesis and mineral nutrient absorption. Biol Trace Elem Res 142:67-76. https://doi.org/10.1007/s12011-010-8742-x

Cooke J, Leishman RM (2016) Consistent alleviation of abiotic stress with silicon addition: a meta-analysis. Funct Ecol 30:1340-1357. https://doi.org/10.1111/1365-2435.12713

Cornelis JT, Delvaux B (2016) Soil processes drive the biological silicon feedback loop. Funct Ecol 30:1298-1310. https://doi.org/10.1111/ 1365-2435.12704

Coskun D, Britto DT, Huynh WQ, Kronzucker HJ (2016) The role of silicon in higher plants under salinity and drought stress. Front Plant Sci 7:1072. https://doi.org/10.3389/fpls.2016.01072

Craine JM, Nippert JB, Elmore AJ, Skibbe AM, Hutchinson SL, Brunsell NA (2012) Timing of climate variability and grassland productivity. Proc Natl Acad Sci U S A 109(9):3401-3405. https://doi.org/10. 1073/pnas.1118438109

Cramer RG, Urano K, Delrot S, Pezzotti M, Shinozaki K (2011) Effects of abiotic stress on plants: a systems biology perspective. BMC Plant Biol 11:163. https://doi.org/10.1186/1471-2229-11-163
Damberg L, AghaKouchak A (2014) Global trends and patterns of drought from space. Theor Appl Climatol 117:441-448. https:// doi.org/10.1007/s00704-013-1019-5

Datnoff LE, Deren CW, Snyder GH (1997) Silicon fertilization for disease management of rice in Florida. Crop Prot 16:525-531. https:// doi.org/10.1016/S0261-2194(97)00033-1

Debona D, Rodrigues FA, Rios JA, Nascimento KJT, Silva LC (2014) The effect of silicon on antioxidant metabolism of wheat leaves infected by Pyricularia oryzae. Plant Pathol 63:581-589. https:// doi.org/10.1111/ppa.12119

Demidchik V (2015) Mechanisms of oxidative stress in plants: from classical chemistry to cell biology. Environ Exp Bot 109:212-228. https://doi.org/10.1016/j.envexpbot.2014.06.021

Deshmukh R, Bélanger RR (2016) Molecular evolution of aquaporins and silicon influx in plants. Funct Ecol 30:1277-1285. https://doi. org/10.1111/1365-2435.12570

Deshmukh RK, Vivancos J, Ramakrishnan G, Guérin V, Carpentier G, Sonah H, Labbé C, Isenring P, Belzile FJ, Bélanger RR (2015) A precise spacing between the NPA domains of aquaporins is essential for silicon permeability in plants. Plant J 83(3):489-500. https://doi. org/10.1111/tpj.12904

Detmann KC, Araújo WL, Martins SCV, Sanglard LMVP, Reis JV, Detmann E, Rodrigues F, Nunes-Nesi A, Fernie AR, DaMatta FM (2012) Silicon nutrition increases grain yield, which, in turn, exerts a feed-forward stimulation of photosynthetic rates via enhanced mesophyll conductance and alters primary metabolism in rice. New Phytol 196:752-762. https://doi.org/10.1111/j.1469-8137.2012. 04299.x

Diogo VCR, Wydra K (2007) Silicon-induced basal resistance in tomato against Ralstonia solanacearum is related to modification of pectic cell wall polysaccharide structure. Physiol Mol Plant Pathol 70:120 129. https://doi.org/10.1016/j.pmpp.2007.07.008

Douma JC, Pautasso M, Venette RC, Robinet C, Hemerik L, Mourits MCM, Schans J, van der Werf W (2016) Pathway models for analysing and managing the introduction of alien plant pests - an overview and categorization. Ecol Model 339:58-67. https://doi. org/10.1016/j.ecolmodel.2016.08.009

Dow M, An SQ, O'Connell A (2017) Bacterial diseases. In: Thomas B, Murray GB and Murphy JD (Eds) Encyclopedia of applied plant sciences. Volume 3: crop systems. 2nd edn. Elsevier Amsterdam, pp. 59-68. https://doi.org/10.1016/B978-0-12-394807-6.00051-4

Eneji AE, Inanaga S, Muranaka S, Li J, Hattori T, An P, Tsuji W (2008) Growth and nutrient use in four grasses under drought stress as mediated by silicon fertilizers. J Plant Nutr 31:355-365. https:// doi.org/10.1080/01904160801894913

Epstein E (1999) Silicon. Annu Rev Plant Physiol Plant Mol Biol 50: 641-664. https://doi.org/10.1146/annurev.arplant.50.1.641

Etesami H, Jeong BR (2018) Silicon (Si): review and future prospects on the action mechanisms in alleviating biotic and abiotic stresses in plants. Ecotoxicol Environ Saf 147:881-896. https://doi.org/10. 1016/j.ecoenv.2017.09.063

Farooq AM, Ali S, Hameed A, Ishaque W, Mahmood K, Iqbal Z (2013) Alleviation of cadmium toxicity by silicon is related to elevated photosynthesis, antioxidant enzymes; suppressed cadmium uptake and oxidative stress in cotton. Ecotoxicol Environ Saf 96:242-249. https://doi.org/10.1016/j.ecoenv.2013.07.006

Farooq M, Wahid A, Kobayashi N, Fujita D, Basra SMA (2009) Plant drought stress: effects, mechanisms and management. Agron Sustain Dev 29:185-212. https://doi.org/10.1051/agro:2008021

Farooq AM, Dietz KJ (2015) Silicon as versatile player in plant and human biology: overlooked and poorly understood. Front Plant Sci 6:994. https://doi.org/10.3389/fpls.2015.00994

Ferreira HA, Araújo do Nascimento CW, Datnoff LE, de Sousa Nunes GH, Preston W, de Souza EB, de Lima Ramos Mariano R (2015) Effects of silicon on resistance to bacterial fruit blotch and growth of 
melon. Crop Prot 78:277-283. https://doi.org/10.1016/j.cropro. 2015.09.025

Fu YQ, Shen H, Wu DM, Cai KZ (2012) Silicon-mediated amelioration of $\mathrm{Fe}^{2+}$ toxicity in rice (Oryza sativa L.) roots. Pedosphere 22(6): 795-802. https://doi.org/10.1016/S1002-0160(12)60065-4

García AJ, Pallás V (2015) Viral factors involved in plant pathogenesis. Curr Opin Virol 11:21-30. https://doi.org/10.1016/j.coviro.2015.01. 001

Genga A, Mattana M, Coraggio I, Locatelli F, Piffanelli P, Consonni R (2011) Plant metabolomics: a characterisation of plant responses to abiotic stresses. In: Shanker A (ed) Abiotic stress in plants - mechanisms and adaptations. InTech, Rijeka. https://doi.org/10.5772/ 23844

Ghanmi D, McNally DJ, Benhamou N, Menzies JG, Bélanger RR (2004) Powdery mildew of Arabidopsis thaliana: a pathosystem for exploring the role of silicon in plant-microbe interactions. Physiol Mol Plant Pathol 64:189-199. https://doi.org/10.1016/j.pmpp.2004.07. 005

Gilioli G, Schrader G, Baker RHA, Ceglarska E, Kertész VK, Lövei G, Navajas M, Rossi V, Tramontini S, van Lenteren JC (2014) Environmental risk assessment for plant pests: a procedure to evaluate their impacts on ecosystem services. Sci Total Environ 468469:475-486. https://doi.org/10.1016/j.scitotenv.2013.08.068

Gong B, Zhang GF (2014) Interactions between plants and herbivores: a review of plant defense. Acta Ecol Sin 34:325-336. https://doi.org/ 10.1016/j.chnaes.2013.07.010

Gong HJ, Randall DP, Flowers TJ (2006) Silicon deposition in the root reduces sodium uptake in rice seedlings by reducing bypass flow. Plant Cell Environ 111:1-9. https://doi.org/10.1111/j.1365-3040. 2006.01572.x

Gonzalo JM, Lucena JJ, Hernández-Apaolaza L (2013) Effect of silicon addition on soybean (Glycine max) and cucumber (Cucumis sativus) plants grown under iron deficiency. Plant Physiol Biochem 70:455461. https://doi.org/10.1016/j.plaphy.2013.06.007

Gostinčar C, Grube M, Gunde-Cimerman N (2011) Evolution of fungal pathogens in domestic environments? Fungal Biol 115:1008-1018. https://doi.org/10.1016/j.funbio.2011.03.004

Goyal A, Manoharachary C (2014) Future challenges in crop protection against fungal pathogens. Springer-Verlag, New York. https://doi. org/10.1007/978-1-4939-1188-2

Gu HH, Qiu H, Tian T, Zhan SS, Deng Teng HB, Chaney LR, Wang SZ, Tang YT, Morel JL, Qiu RL (2011) Mitigation effects of silicon rich amendments on heavy metal accumulation in rice (Oryza sativa L.) planted on multi-metal contaminated acidic soil. Chemosphere 83: 1234-1240. https://doi.org/10.1016/j.chemosphere.2011.03.014

Guntzer F, Keller C, Meunier JD (2012) Benefits of plant silicon for crops: a review. Agron Sustain Dev 32:201-213. https://doi.org/ 10.1007/s13593-011-0039-8

Hansen DJ, Dayanandan P, Kaufman PB, Brotherson JD (1976) Ecological adaptations of salt marsh grass Distichlis spicata (Gramineae) and environment factors affecting its growth and distribution. Am J Bot 63:635-650

Hartley ES, DeGabriel LJ (2016) The ecology of herbivore-induced silicon defences in grasses. Funct Ecol 30:1311-1322. https://doi.org/ $10.1111 / 1365-2435.12706$

Hasanuzzaman M, Nahar K, Alam MM, Roychowdhury R, Fujita M (2013) Physiological, biochemical, and molecular mechanisms of heat stress tolerance in plants. Int J Mol Sci 14:9643-9684. https:// doi.org/10.3390/ijms14059643

Hashemi A, Abdolzadeh A, Sadeghipour HR (2010) Beneficial effects of silicon nutrition in alleviating salinity stress in hydroponically grown canola, Brassica napus L. plants. Soil Sci Plant Nutr 56: 244-253. https://doi.org/10.1111/j.1747-0765.2009.00443.x

Hattori T, Inanaga S, Tanimoto E, Lux A, Luxová M, Sugimoto Y (2003) Silicon-induced changes in viscoelastic properties of sorghum root cell walls. Plant Cell Physiol 44:743-749. https://doi.org/10.1093/ $\mathrm{pcp} / \mathrm{pcg} 090$

Hattori T, Inanaga S, Araki H, An P, Morita S, Luxová M, Lux A (2005) Application of silicon enhanced drought tolerance in Sorghum bicolour. Physiol Plant 123(4):459-466. https://doi.org/10.1111/j. 1399-3054.2005.00481.x

Hattori T, Sonobe K, Inanaga S, Morita S (2008) Effects of silicon on photosynthesis of young cucumber seedlings under osmotic stress. J Plant Nutr 31:1046-1058. https://doi.org/10.1080/ 01904160801928380

He CW, Wang LJ, Liu J, Liu X, Li XL, Ma J, Lin YJ, Xu FS (2013) Evidence for 'silicon' within the cell walls of suspension-cultured rice cells. New Phytol 200:700-709. https://doi.org/10.1111/nph. 12401

Heath MC, Stumpf MA (1986) Ultrastructural observations of penetration sites of the cowpea rust fungus in untreated and silicon-depleted French bean cells. Physiol Mol Plant P 29:27-39. https://doi.org/10. 1016/S0048-4059(86)80035-2

Heine G, Tikum G, Horst JW (2007) The effect of silicon on the infection by and spread of Phytium aphanidermatum in single roots of tomato and bitter gourd. J Exp Bot 58:569-577. https://doi.org/10.1093/jxb/ erl232

Hernandez-Apaolaza L (2014) Can silicon partially alleviate micronutrient deficiency in plants? A review. Planta 240:447-458. https://doi. org/10.1007/s00425-014-2119-x

Hobara S, Fukunaga-Yoshida S, Suzuki T, Matsumoto S, Matoh T, Ae N (2016) Plant silicon uptake increases active aluminum minerals in root-zone soil: implications for plant influence on soil carbon. Geoderma 279:45-52. https://doi.org/10.1016/j.geoderma.2016.05. 024

Hodson MJ, Sangster AG (1989) Silica deposition in the inflorescence bracts of wheat (Triticum aestivum L.) II. X-ray microanalysis and backscattered electron imaging. Can J Bot 67:281-287. https://doi. org/10.1139/b89-041

Hodson MJ, White PJ, Mead A, Broadley MR (2005) Phylogenetic variation in the silicon composition of plants. Ann Bot 96:1027-1046. https://doi.org/10.1093/aob/mci255

Huber D, Romheld V, Weimann M (2012) Relationship between nutrition, plant diseases and pests. In: Petra M (ed) Marschner's mineral nutrition of higher plants, 3rd edn. Science Press, Beijing, pp 283298. https://doi.org/10.1016/B978-0-12-384905-2.00010-8

Imtiaz M, Rizwan MS, Mushtaq MA, Ashraf M, Shahzad SM, Yousaf B, Saeed DA, Rizwan M, Nawaz MA, Mehmood S, Tu S (2016) Silicon occurrence, uptake, transport and mechanisms of heavy metals, minerals and salinity enhanced tolerance in plants with future prospects: a review. J Environ Manag 183:521-529. https://doi. org/10.1016/j.jenvman.2016.09.009

Irisarri JGN, Derner JD, Porensry LM, Augustine DT, Reeves JL, Mueller KE (2016) Grazing intensity differentially regulates ANPP response to precipitation in North American semiarid grasslands. Ecol Appl 26(5):1370-1380. https://doi.org/10.1890/15-1332

Jansen MAK, Van Den Noort RE (2000) Ultraviolet-B radiation induces complex alterations in stomatal behaviour. Physiol Plant 110:189 194. https://doi.org/10.1034/j.1399-3054.2000.110207.x

Johnson NS, Benefer MC, Frew A, Griffiths SB, Hartley ES, Karley JA, Rasmann S, Schumann M, Sonnemann I, Robert AMC (2016) New frontiers in belowground ecology for plant protection from rootfeeding insects. Appl Soil Ecol 108:96-107. https://doi.org/10. 1016/j.apsoil.2016.07.017

Johnson NS, Hallett PD, Gillespie TL, Halpin C (2010) Belowground herbivory and root toughness: a potential model system using ligninmodified tobacco. Physiol Entomol 35:186-191. https://doi.org/10. 1111/j.1365-3032.2010.00723.x

Kang JJ, Zhao WZ, Zhu X (2016) Silicon improves photosynthesis and strengthens enzyme activities in the $\mathrm{C}_{3}$ succulent xerophyte 
Zygophyllum xanthoxylum under drought stress. J Plant Physiol 199: 76-86. https://doi.org/10.1016/j.jplph.2016.05.009

Katz O (2015) Silica phytoliths in angiosperms: phylogeny and early evolutionary history. New Phytol 208:642-646. https://doi.org/10. 1111/nph.13559

Kaya C, Tuna L, Higgs D (2006) Effect of silicon on plant growth and mineral nutrition of maize grown under water-stress conditions. $\mathrm{J}$ Plant Nutr 29:1469-1480. https://doi.org/10.1080/ 01904160600837238

Kim YH, Khan AL, Waqas M, Shim JK, Kim DH, Lee KY, Lee IJ (2014) Silicon application to rice root zone influenced the phytohormonal and antioxidant responses under salinity stress. J Plant Growth Regul 33:137-149. https://doi.org/10.1007/s00344-013-9356-2

Kim BS, French E, Caldwell D, Harrington JE, Iyer-Pascuzzi SA (2016) Bacterial wilt disease: host resistance and pathogen virulence mechanisms. Physiol Mol Plant Pathol 95:37-43. https://doi.org/10.1016/ j.pmpp.2016.02.007

Klotzbücher T, Klotzbücher A, Kaiser K, Vetterlein D, Jahn R, Mikutta R (2018) Variable silicon accumulation in plants affects terrestrial carbon cycling by controlling lignin synthesis. Glob Chang Biol 24: 183-189. https://doi.org/10.1111/gcb.13845

Klotzbücher T, Marxen A, Vetterlein D, Schneiker J, Türke M, Sinh NV, Manh NH, Chien HV, Marquez L, Villareal S, Bustamante VJ, Jahn R (2015) Plant-available silicon in paddy soils as a key factor for sustainable rice production in Southeast Asia. Basic Appl Ecol 16: 665-673. https://doi.org/10.1016/j.baae.2014.08.002

Kogan F, Stark R, Gitelson A, Jargalsaikhan L, Dugrajav C, Tsooj S (2004) Derivation of pasture biomass in Mongolia from AVHRRbased vegetation health indices. Int J Remote Sens 25(14):2889 2896. https://doi.org/10.1080/01431160410001697619

Kostic L, Nikolic N, Bosnic D, Samardzic J, Nikolic M (2017) Silicon increases phosphorus $(\mathrm{P})$ uptake by wheat under low $\mathrm{P}$ acid soil conditions. Plant Soil. https://doi.org/10.1007/s11104-017-3364-0

Kurabachew H, Wydra K (2014) Induction of systemic resistance and defense-related enzymes after elicitation of resistance by rhizobacteria and silicon application against Ralstonia solanacearum in tomato (Solanum lycopersicum). Crop Prot 57:17. https://doi.org/10.1016/j.cropro.2013.10.021

Lehmann S, Serrano M, L'Haridon F, Tjamos ES, Metraux JP (2015) Reactive oxygen species and plant resistance to fungal pathogens. Phytochemistry 112:54-62. https://doi.org/10.1016/j.phytochem. 2014.08.027

Levitt J (1980) Responses of plants to environmental stresses. Vol. 1: chilling, freezing, and high temperature stresses, 2nd edn. Academic Press, New York, pp 102-106. https://doi.org/10.1016/ B978-0-12-445501-6.50008-7

Li P, Song AL, Li ZJ, Fan FL, Liang YC (2015a) Silicon ameliorates manganese toxicity by regulating both physiological processes and expression of genes associated with photosynthesis in rice (Oryza sativa L.) Plant Soil 397:289-301. https://doi.org/10.1007/s11104015-2626-y

Liang YC, Nikolic M, Bélanger R, Gong G, Song A (2015) Silicon biogeochemistry and bioavailability in soil. In: Silicon in agriculture: from theory to practice. Springer, Netherlands, pp 45-68. https://doi.org/10.1007/978-94-017-9978-2 3

Liang YC, Sun WC, Zhu YG, Christie P (2007) Mechanisms of siliconmediated alleviation of abiotic stresses in higher plants: a review. Environ Pollut 147:422-428. https://doi.org/10.1016/j.envpol.2006. 06.008

Liang YC, Si J, Römheld V (2005a) Silicon uptake and transport is an active process in Cucumis sativus L. New Phytol 167:797-804. https://doi.org/10.1111/j.1469-8137.2005.01463.x

Liang YC, Wong JWC, Wei L (2005b) Silicon-mediated enhancement of cadmium tolerance in maize (Zea mays L.) grown in cadmium contaminated soil. Chemosphere 58:475-483. https://doi.org/10.1016/j. chemosphere.2004.09.034
Liang YC, Sun WC, Si J, Römheld V (2005c) Effect of foliar- and rootapplied silicon on the enhancement of induced resistance in Cucumis sativus to powdery mildew. Plant Pathol 54:678-685. https://doi.org/10.1111/j.1365-3059.2005.01246.x

Liang YC, Zhu J, Li ZJ, Chu GX, Ding YF, Zhang J, Sun WC (2008) Role of silicon in enhancing resistance to freezing stress in two contrasting winter wheat cultivars. Environ Exp Bot 64:286-294. https://doi.org/10.1016/j.envexpbot.2008.06.005

Lukačová Z, Švubová R, Kohanová J, Lux A (2013) Silicon mitigates the $\mathrm{Cd}$ toxicity in maize in relation to cadmium translocation, cell distribution, antioxidant enzymes stimulation and enhanced endodermal apoplasmic barrier development. Plant Growth Regul 70:89103. https://doi.org/10.1007/s10725-012-9781-4

Lux A, Luxová M, Abe J, Tanimoto E, Hattori T, Inanaga S (2003) The dynamics of silicon deposition in the sorghum root endodermis. New Phytol 158:437-441. https://doi.org/10.1046/j.1469-8137. 2003.00764.x

Luyckx M, Hausman JF, Lutts S, Guerriero G (2017) Silicon and plants: current knowledge and technological perspectives. Front Plant Sci 8: 411. https://doi.org/10.3389/fpls.2017.00411

Ma J, Cai HM, He CW, Zhang WJ, Wang LJ (2014) A hemicellulosebound form of silicon inhibits cadmium ion uptake in rice (Oryza sativa) cells. New Phytol 206:1063-1074. https://doi.org/10.1111/ nph. 13276

Ma JF, Miyake Y, Takahashi E (2001) Silicon as a beneficial element for crop plants. In: Datonoff L, Snyder G, Korndorfer G (eds) Silicon in agriculture. Elsevier Science, New York, pp 17-39. https://doi.org/ 10.1016/S0928-3420(01)80006-9

Ma JF, Takahashi E (1990) Effect of silicon on the growth and phosphorus uptake of rice. Plant Soil 126:115-119. https://doi.org/10.1007/ BF00041376

Ma JF, Takahashi E (2002) Soil, fertilizer, and plant silicon research in Japan. Elsevier, Amsterdam. https://doi.org/10.1016/B978044451166-9/50004-X

Ma JF, Yamaji N (2006) Silicon uptake and accumulation in higher plants. Trends Plant Sci 11:392-397. https://doi.org/10.1016/j. tplants.2006.06.007

Ma JF, Yamaji N (2008) Functions and transport of silicon in plants. Cell Mol Life Sci 65:3049-3057. https://doi.org/10.1007/s00018-0087580-x

Ma JF, Yamaji N (2015) A cooperative system of silicon transport in plants. Trends Plant Sci 20:435-442. https://doi.org/10.1016/j. tplants.2015.04.007

Ma JF, Yamaji N, Mitani N, Xu XY, Su YH, McGrath PS, Zhao FJ (2008) Transporters of arsenite in rice and their role in arsenic accumulation in rice grain. Proc Natl Acad Sci U S A 105:9931-9935. https://doi. org/10.1073/pnas.0802361105

Marmiroli M, Pigoni V, Savo-Sardaro ML, Marmiroli N (2014) The effect of silicon on the uptake and translocation of arsenic in tomato (Solanum lycopersicum L.) Environ Exp Bot 99:9-17. https://doi. org/10.1016/j.envexpbot.2013.10.016

Massey PF, Ennos AR, Hartley ES (2007) Grasses and the resource availability hypothesis: the importance of silica-based defences. J Ecol 95:414-424. https://doi.org/10.1111/j.1365-2745.2007.01223.x

Mateos-Naranjo E, Gallé A, Florez-Sarasa I, Perdomo AJ, Galmés J, Ribas-Carbó M, Flexas J (2015) Assessment of the role of silicon in the Cu-tolerance of the $\mathrm{C} 4$ grass Spartina densiflora. J Plant Physiol 178:74-83. https://doi.org/10.1016/j.jplph.2015.03.001

Meharg C, Meharg AA (2015) Silicon, the silver bullet for mitigating biotic and abiotic stress, and improving grain quality, in rice? Environ Exp Bot 120:8-17. https://doi.org/10.1016/j.envexpbot. 2015.07.001

Menzies JG, Ehret DL, Glass ADM, Helmer T, Koch C, Seywerd F (1991) Effects of soluble silicon on the parasitic fitness of Sphaerotheca fuliginea on Cucumis sativus. Phytopathology 81: 84-88. https://doi.org/10.1094/Phyto-81-84 
Ming DF, Pei ZF, Naeem MS, Gong HJ, Zhou WJ (2012) Silicon alleviates PEG-induced water-deficit stress in upland rice seedlings by enhancing osmotic adjustment. J Agron Crop Sci 198:14-26. https://doi.org/10.1111/j.1439-037X.2011.00486.x

Mitani N, Ma JF, Iwashita T (2005) Identification of the silicon form in xylem sap of rice (Oryza sativa L.) Plant Cell Physiol 46:279-283. https://doi.org/10.1093/pcp/pci018

Nagajyoti PC, Lee KD, Sreekanth TVM (2010) Heavy metals, occurrence and toxicity for plants: a review. Environ Chem Lett 8:199216. https://doi.org/10.1007/s10311-010-0297-8

Narayanasamy P (2011) Microbial plant pathogens-detection and disease diagnosis: detection of bacterial and phytoplasmal pathogens. Springer, Netherlands, pp 5-169. https://doi.org/10.1007/978-90481-9769-9

Nascimento TJK, Debona D, Silveira RP, Silva CL, DaMatta MF, Rodrigues ÁF (2016) Silicon-induced changes in the antioxidant system reduce soybean resistance to frogeye leaf spot. J Phytopathol 164:768-778. https://doi.org/10.1111/jph.12497

Neal C, Neal M, Reynolds B, Maberly CS, May L, Ferrier CR, Smith J, Parker EJ (2005) Silicon concentrations in UK surface waters. J Hydrol 304(2005):75-93. https://doi.org/10.1016/j.jhydrol.2004. 07.023

Neu S, Schaller J, Dudel ET (2017) Silicon availability modifies nutrient use efficiency and content, C:N:P stoichiometry, and productivity of winter wheat (Triticum aestivum L.) Sci Rep 7:40829. https://doi. org/10.1038/srep40829

Nicol JM, Turner SJ, Coyne DL, Nijs L, Hockland S, Maafi ZT (2011) Current nematode threats to world agriculture. In: Jones J, Gheysen G, Fenoll C (eds) Genomics and molecular genetics of plant-nematode interactions. Springer, Netherlands, pp 21-43. https://doi.org/ 10.1007/978-94-007-0434-3 2

Ortega L, Fry SC, Taleisnik E (2006) Why are Chloris gayana leaves shorter in salt-affected plants? Analyses in the elongation zone. J Exp Bot 57:3945-3952. https://doi.org/10.1093/jxb/erl168

Pavlovic J, Samardzic J, Maksimović V, Timotijevic G, Stevic N, Laursen HK, Hansen HT, Husted S, Schjoerring JK, Liang YC, Nikolic M (2013) Silicon alleviates iron deficiency in cucumber by promoting mobilization of iron in the root apoplast. New Phytol 198:10961107. https://doi.org/10.1111/nph.12213

Pearson M (2017) Viral diseases. In: Thomas B, Murray GB, Murphy JD (eds) Encyclopedia of applied plant sciences. Volume 3: crop systems, 2nd edn. Elsevier, pp 137-147. https://doi.org/10.1016/B9780-12-394807-6.00057-5

Pham CH, Min J, Gu MB (2004) Pesticide induced toxicity and stress response in bacterial cells. Bull Environ Contam Toxicol 72:380 386. https://doi.org/10.1007/s00128-003-8845-6

Pei ZF, Ming DF, Liu D, Wan GL, Geng XX, Gong HJ, Zhou WJ (2010) Silicon improves the tolerance to water-deficit stress induced by polyethylene glycol in wheat (Triticum aestivum L.) seedlings. J Plant Growth Regul 29:106-115. https://doi.org/10.1007/s00344009-9120-9

Pokrovski SG, Schott J, Farges F, Hazemann JL (2003) Iron (III)-silica interactions in aqueous solution: Insights from X-ray absorption fine structure spectroscopy. Geochim Cosmochim Acta 67:3559-3573. https://doi.org/10.1016/S0016-7037(03)00160-1

Pontigo S, Ribera A, Gianfreda L, Mora MDLL, Nikolic M, Cartes P (2015) Silicon in vascular plants: uptake, transport and its influence on mineral stress under acidic conditions. Planta 242:23-37. https:// doi.org/10.1007/s00425-015-2333-1

Prudhomme C, Giuntoli I, Robinson LE, Clark BD, Arnell WN, Dankers R, Fekete MB, Franssen W, Gerten D, Gosling NS, Hagemann S, Hannah MD, Kim H, Masaki Y, Satoh Y, Stacke T, Wada Y, Wissern D (2014) Hydrological droughts in the 21st century, hotspots and uncertainties from a global multimodel ensemble experiment. Proc Natl Acad Sci U S A 111:3262-3267. https://doi.org/10.1073/pnas. 1222473110
Rasool S, Hameed A, Azooz MM, Muneeb-u-Rehman, Siddiqi TO, Parvaiz Ahmad P (2013) Salt stress: causes, types and responses of plants. In: Ahmad P, Azooz MM, Prasad MNV (eds) Ecophysiology and responses of plants under salt stress. Springer, New York, pp 1-24. https://doi.org/10.1007/978-1-4614-4747-4_1

Raven JA (2001) Silicon transport at the cell and tissue level. In: Datnoff LE, Snyder GH, Korndörfer GH (eds) Silicon in agriculture. Elsevier, Amsterdam, pp 41-55. https://doi.org/10.1016/s09283420(01)80007-0

Ray M, Ray A, Dash S, Mishra A, Achary KG, Nayak S, Singh S (2017) Fungal disease detection in plants: traditional assays, novel diagnostic techniques and biosensors. Biosens Bioelectron 87:708-723. https://doi.org/10.1016/j.bios.2016.09.032

Renton M, Childs S, Standish R, Shackelford N (2013) Plant migration and persistence under climate change in fragmented landscapes: does it depend on the key point of vulnerability within the lifecycle? Ecol Model 249:50-58. https://doi.org/10.1016/j.ecolmodel.2012. 07.005

Rios JJ, Martinez-Ballesta M, Ruiz JM, Blasco Leòn B, Carvajal M (2017) Silicon-mediated improvement in plant salinity tolerance: the role of aquaporins. Front Plant Sci 8:948. https://doi.org/10. 3389/fpls.2017.00948

Rizwan M, Ali S, Ibrahim M, Farid M, Adrees M, Bharwana AS, Zia-urRehman M, Qayyum FM, Abbas F (2015) Mechanisms of siliconmediated alleviation of drought and salt stress in plants: a review. Environ Sci Pollut Res 22:15416-15431. https://doi.org/10.1007/ s11356-015-5305-x

Savant NK, Snyder GH, Datnoff LE (1997) Silicon management and sustainable rice production. Adv Agron 58:151-199. https://doi. org/10.1080/00103629709369870

Savvides A, Ali S, Tester M, Fotopoulos V (2016) Chemical priming of plants against multiple abiotic stresses: mission possible? Trends Plant Sci 21:329-340. https://doi.org/10.1016/j.tplants.2015.11.003

Schaller J, Brackhage C, Gessner MO, Bäuker E, Gert Dudel E (2012) Silicon supply modifies C:N:P stoichiometry and growth of Phragmites australis. Plant Biol 14:392-396. https://doi.org/10. 1111/j.1438-8677.2011.00537.x

Schieber M, Chandel NS (2014) ROS function in redox signaling and oxidative stress. Curr Biol 24:R453-R462. https://doi.org/10.1016/j. cub.2014.03.034

Schönbach P, Wan HW, Gierus M, Bai YF, Müller K, Liu LJ, Susenbeth A, Taube F (2010) Grassland responses to grazing: effects of grazing intensity and management system in an Inner Mongolian steppe ecosystem. Plant Soil 340(1):103-115. https://doi.org/10.1007/ s11104-010-0366-6

Shen X, Li X, Li Z, Li J, Duan L, Eneji AE (2010a) Growth, physiological attributes and antioxidant enzyme activities in soybean seedlings treated with or without silicon under UV-B radiation stress. J Agron Crop Sci 196:431-439. https://doi.org/10.1111/j.1439-037X. 2010.00428.x

Shen XF, Zhou YY, Duan LS, Li ZH, Eneji AE, Li JM (2010b) Silicon effects on photosynthesis and antioxidant parameters of soybean seedlings under drought and ultraviolet-B radiation. J Plant Physiol 167:1248-1252. https://oi.org/10.1016/j.jplph.2010.04.011

Shi Y, Wang YC, Flowers JT, Gong HJ (2013) Silicon decreases chloride transport in rice (Oryza sativa L.) in saline conditions. J Plant Physiol 170:847-853. https://doi.org/10.1016/j.jplph.2013.01.018

Skjemstad JO, Fitzpatrick RW, Zarcinas BA, Thompson CH (1992) Genesis of Podzols on coastal dunes in southern Queensland: II. Geochemistry and forms of elements as deduced from various soil extraction procedures. Aust J Soil Sci 30:615-644. https://doi.org/ 10.1071/SR9920645

Soininen ME, Bråthen AK, Jusdado HGJ, Reidinger S, Hartley ES (2013) More than herbivory: levels of silica-based defences in grasses vary with plant species, genotype and location. Oikos 122:30-41. https:// doi.org/10.1111/j.1600-0706.2012.20689.x 
Song AL, Li P, Fan FL, Li ZJ, Liang YC (2014) The effect of silicon on photosynthesis and expression of its relevant genes in rice (Oryza sativa L.) under high-Zn stress. PLoS One 9(11):e113782. https:// doi.org/10.1371/journal.pone

Song AL, Xue GF, Cui PY, Fan FL, Liu HF, Yin C, Sun WC, Liang YC (2016) The role of silicon in enhancing resistance to bacterial blight of hydroponic- and soil-cultured rice. Sci Rep 6:24640. https://doi. org/10.1038/srep24640

Song AL, Fan FL, Yin C, Wen SL, Zhang YL, Fan XP, Liang YC (2017) The effects of silicon fertilizer on denitrification potential and associated genes abundance in paddy soil. Biol Fertil Soils 53:627-638. https://doi.org/10.1007/s00374-017-1206-0

Sommer M, Kaczorek D, Kuzyakov Y, Breuer J (2006) Silicon pools and fluxes in soils and landscapes - a review. J Plant Nutr Soil Sci 169: 310-329. https://doi.org/10.1002/jpln.200521981

Soundararajan P, Sivanesan I, Jana S, Jeong BR (2014) Influence of silicon supplementation on the growth and tolerance to high temperature in Salvia splendens. Hortic Environ Biotechnol 55:271-279. https://doi.org/10.1007/s13580-014-0023-8

Sumner ME, Noble AD (2003) Soil acidification: the world story. In: Rengel Z (ed) Handbook of soil acidity. Marcel Dekker, New York, pp 1-28. https://doi.org/10.1201/9780203912317.ch1

Suzuki S, Ma JF, Yamamoto N, Toshiaki U (2012) Silicon deficiency promotes lignin accumulation in rice. Plant Biotechnol 29:391394. https://doi.org/10.5511/plantbiotechnology.12.0416a

Tripathi DK, Singh S, Singh VP, Prasad SM, Dubey NK, Chauhan DK (2017) Silicon nanoparticles more effectively alleviated UV-B stress than silicon in wheat (Triticum aestivum) seedlings. Plant Physiol Biochem 110:70-81. https://doi.org/10.1016/j.plaphy.2016.06.026

Tripathi DK, Singh S, Singh VP, Prasad SM, Chauhan DK, Dubey NK (2016a) Silicon nanoparticles more efficiently alleviate arsenate toxicity than silicon in maize cultiver and hybrid differing in arsenate tolerance. Front Environ Sci 4:46. https://doi.org/10.3389/fenvs. 2016.00046

Tripathi, DK, Singh S, Singh S, Chauhan DK, Dubey NK, Prasad R (2016b) Silicon as a beneficial element to combat the adverse effect of drought in agricultural crops. In: Ahmad (ed) Water stress and crop plants: a sustainable approach, pp 682-694. https://doi.org/10. 1002/9781119054450.ch39

Tripathi DK, Singh VP, Prasad SM, Chauhan DK, Dubey NK (2015) Silicon nanoparticles (SiNp) alleviate chromium (VI) phytotoxicity in Pisum sativum (L.) seedlings. Plant Physiol Biochem 96:189198. https://doi.org/10.1016/j.plaphy.2015.07.026

Tripathi P, Tripathi RD, Singh RP, Dwivedi S, Goutam D, Shri M, Trivedi PK, Chakrabarty D (2013) Silicon mediates arsenic tolerance in rice (Oryza sativa L.) through lowering of arsenic uptake and improved antioxidant defence system. Ecol Eng 52:96-103. https://doi.org/10. 1016/j.ecoleng.2012.12.057

Tubaña BS, Heckman JR (2015) Silicon in soils and plants. In: Rodrigues FA, Datnoff LE (eds) Silicon and plant diseases. Springer International Publishing, Switzerland, pp 7-51. https://doi.org/10. 1007/978-3-319-22930-0 2

Tuna AL, Kaya C, Higgs D, Murillo-Amador B, Aydemir S, Girgin RA (2008) Silicon improves salinity tolerance in wheat plants. Environ Exp Bot 62:10-16. https://doi.org/10.1016/j.envexpbot.2007.06.006

Van Bockhaven J, Spíchal L, Novák O, Strnad M, Asano T, Kikuchi S, Höfte M, De Vleesschauwer D (2015) Silicon induces resistance to the brown spot fungus Cochliobolus miyabeanus by preventing the pathogen from hijacking the rice ethylene pathway. New Phytol 206:761-773. https://doi.org/10.1111/nph.13270

Vivancos J, Deshmukh R, Grégoire C, Rémus-Borel W, Belzile F, Bélanger RR (2016) Identification and characterization of silicon efflux transporters in horsetail (Equisetum arvense). J Plant Physiol 200:82-89. https://doi.org/10.1016/j.jplph.2016.06.011

Vivancos J, Labbé C, Menzies GJ, Bélanger RR (2015) Silicon-mediated resistance of Arabidopsis against powdery mildew involves mechanisms other than the salicylic acid (SA)-dependent defence pathway. Mol Plant Pathol 16:572-582. https://doi.org/10.1111/ mpp. 12213

Walters DR, Bingham IJ (2007) Influence of nutrition on disease development caused by fungal pathogens: implications for plant disease control. Ann Appl Biol 151:307-324. https://doi.org/10.1111/j. 1744-7348.2007.00176.x

Wang M, Gao LM, Dong SY, Sun YM, Shen QR, Guo SW (2017) Role of silicon on plant-pathogen interactions. Front Plant Sci 8:701. https://doi.org/10.3389/fpls.2017.00701

Wang XS, Han JG (2007) Effects of $\mathrm{NaCl}$ and silicon on ion distribution in the roots, shoots and leaves of two alfalfa cultivars with different salt tolerance. Soil Sci Plant Nutr 53:278-285. https://doi.org/10. 1111/j.1747-0765.2007.00135.x

Weiss A, Herzog A (1978) Isolation and characterization of a siliconorganic complex from plants. In: Gendz G, Lindgrist I, RunnströmReio V (eds) Biochemistry of silicon and related problems. Plenum Press, New York, pp 109-127. https://doi.org/10.1007/978-1-46134018-8 5

Wu W, Huang JL, Cui KH, Nie LX, Wang Q, Yang F, Shah F, Yao FX, Peng SB (2012) Sheath blight reduces stem breaking resistance and increases lodging susceptibility of rice plants. Field Crop Res 128: 101-108. https://doi.org/10.1016/j.fcr.2012.01.002

Wu JW, Geilfus CM, Pitann B, Mühling KH (2016a) Silicon-enhanced oxalate exudation contributes to alleviation of cadmium toxicity in wheat. Environ Exp Bot 131:10-18. https://doi.org/10.1016/j. envexpbot.2016.06.012

Wu C, Zou Q, Xue SG, Pan WS, Huang L, Hartley W, Mo JY, Wong MH (2016b) The effect of silicon on iron plaque formation and arsenic accumulation in rice genotypes with different radial oxygen loss (ROL). Environ Pollut 212:27-33. https://doi.org/10.1016/j. envpol.2016.01.004

Xu DH, Fang XW, Zhang RY, Gao TP, Bu BY, Du GZ (2015) Influences of nitrogen, phosphorus and silicon addition on plant productivity and species richness in an alpine meadow. AoB Plants 7:plv125. https://doi.org/10.1093/aobpla/plv125

Yamaji N, Sakurai G, Mitani-Ueno N, Ma JF (2015) Orchestration of three transporters and distinct vascular structures in node for intervascular transfer of silicon in rice. Proc Natl Acad Sci U S A 112:11401-11406. https://doi.org/10.1073/pnas.1508987112

Yin LN, Wang SW, Li JY, Tanaka K, Oka M (2013) Application of silicon improves salt tolerance through ameliorating osmotic and ionic stresses in the seedling of Sorghum bicolor. Acta Physiol Plant 35: 3099-3107. https://doi.org/10.1007/s11738-013-1343-5

Zhang GL, Cui YX, Ding XW, Dai QG (2013) Stimulation of phenolic metabolism by silicon contributes to rice resistance to sheath blight. J Plant Nutr Soil Sci 176:118-124. https://doi.org/10.1002/jpln. 201200008

Zhu JK (2016) Abiotic stress signaling and responses in plants. Cell 167: 313-324. https://doi.org/10.1016/j.cell.2016.08.029

Zhu YX, Gong HJ (2014) Beneficial effects of silicon on salt and drought tolerance in plants. Agron Sustain Dev 34:455-472. https://doi.org/ 10.1007/s13593-013-0194-1

Zhu YX, Guo J, Feng R, Jia JH, Han WH, Gong HJ (2016) The regulatory role of silicon on carbohydrate metabolism in Cucumis sativus L. under salt stress. Plant Soil 406:231-249. https://doi.org/10.1007/ s11104-016-2877-2

Zia Z, Bakhat HF, Saqib ZA, Shah GM, Fahad S, Ashraf MR, Hammad HM, Naseem W, Shahid M (2017) Effect of water management and silicon on germination, growth, phosphorus and arsenic uptake in rice. Ecotoxicol Environ Saf 144:11-18. https://doi.org/10.1016/j.ecoenv. 2017.06.004 
References of the meta-analysis

Abbas T, Balal RM, Shahid MA, Pervez MA, Ayyub CM, Aqueel MA, Javaid MM (2015) Silicon-induced alleviation of $\mathrm{NaCl}$ toxicity in okra (Abelmoschus esculentus) is associated with enhanced photosynthesis, osmoprotectants and antioxidant metabolism. Acta Physiol Plant 37:6. https://doi.org/10.1007/s11738-014-1768-5

Abdalla MM (2011) Beneficial effects of diatomite on the growth, the biochemical contents and polymorphic DNA in Lupinus albus plants grown under water stress. Agric Biol J N Am 2:207-220. https://doi.org/10.5251/abjna.2011.2.2.207.220

Ahmed M, Hassen F, Khurshid Y (2011) Does silicon and irrigation have impact on drought tolerance mechanism of sorghum? Agric Water Manage 98:1808-1812. https://doi.org/10.1016/j.agwat.2011.07. 003

Ahmed M, Qadeer U, Ahmed ZI, Hassan F (2016) Improvement of wheat (Triticum aestivum) drought tolerance by seed priming with silicon. Arch Agron Soil Sci 62(3):299-315. https://doi.org/10.1080/ 03650340.2015.1048235

Ahmad F, Rahmatullah AT, Maqsood MA, Tahir MA, Kanwal S (2007) Effect of silicon application on wheat (Triticum aestivum L.) growth under water deficiency stress. Emir J Food Agric 19(2):1-7. https:// doi.org/10.9755/ejfa.v12i1.5170

Al-aghabary K, Zhu Z, Shi Q (2005) Influence of silicon supply on chlorophyll content, chlorophyll fluorescence, and antioxidative enzyme activities in tomato plants under salt stress. J Plant Nutr 27: 2101-2115. https://doi.org/10.1081/PLN-200034641

Ali A, Basra SM, Ahmad R, Wahid A (2009) Optimizing silicon application to improve salinity tolerance in wheat. Soil Environ 2:136144

Ali S, Farooq MA, Yasmeen T, Hussain S, Arif MS, Abbas F, Bharwana SA, Zhang GP (2013) The influence of silicon on barley growth, photosynthesis and ultra-structure under chromium stress. Ecotoxicol Environ Saf 89:66-72. https://doi.org/10.1016/j.ecoenv. 2012.11.015

Ashraf M, Rahmatullah, Afzal M, Ahmed R, Mujeeb F, Sarwar A, Ali L (2010) Alleviation of detrimental effects of $\mathrm{NaCl}$ by silicon nutrition in salt-sensitive and salt-tolerant genotypes of sugarcane (Saccharum officinarum L.) Plant Soil 326:381-391. https://doi. org/10.1007/s11104-009-0019-9

Datnoff LE, Rodrigues LA (2005) The role of silicon in suppressing rice diseases. APSnet Features. https://doi.org/10.1094/APSnetFeature2005-0205

Elawad SH, Allen LH, Gascho GJ (1985) Influence of UV-B radiation and soluble silicates on the growth and nutrient concentration of sugarcane. Soil Crop Sci Soc Fla 44:134-141

Garg N, Bhandari P (2016) Interactive effects of silicon and arbuscular mycorrhiza in modulating ascorbate-glutathione cycle and antioxidant scavenging capacity in differentially salt-tolerant Cicer arietinum L. genotypes subjected to long-term salinity. Protoplasma 253:1325-1345. https://doi.org/10.1007/s00709-0150892-4

Kardoni F, Mosavi SJS, Parande S, Torbaghan ME (2013) Effect of salinity stress and silicon application on yield and component yield offaba bean (Viciafaba). Int J Agric Crop Sci 6(12):814-818

Keeping MG, Meyer JH (2002) Calcium silicate enhances resistance of sugarcane to the African stalk borer Eldana saccharina Walker (Lepidoptera: Pyralidae). Agric Forest Entomol 4:265-274. https:// doi.org/10.1046/j.1461-9563.2002.00150.x

Li HL, Zhu YX, Hu YH, Han WH, Gong HJ (2015b) Beneficial effects of silicon in alleviating salinity stress of tomato seedlings grown under sand culture. Acta Physiol Plant 37:71. https://doi.org/10.1007/ s11738-015-1818-7

Liu JG, Zhang HM, Zhang YX, Chai TY (2013) Silicon attenuates cadmium toxicity in Solanum nigrum L. by reducing cadmium uptake and oxidative stress. Plant Physiol Biochem 68:1-7. https://doi.org/ 10.1016/j.plaphy.2013.03.018

Meyer JH, Keeping MG (2005) Impact of silicon in alleviating biotic stress in sugarcane in South Africa. Proc S Afr Sugar Technol Assoc 23:14-18

Ning DF, Song AL, Fan FL, Li ZJ, Liang YC (2014) Effects of slag-based silicon fertilizer on rice growth and brown-spot resistance. PLoS One 9(7):e102681. https://doi.org/10.1371/journal.pone.0102681

Pascual MB, Echevarria V, Gonzalo MJ, Hernandez-Apaolaza L (2016) Silicon addition to soybean (Glycine max L.) plants alleviate zinc deficiency. Plant Physiol Biochem 108:132-138. https://doi.org/10. 1016/j.plaphy.2016.07.008

Polanco LR, Rodrigues FA, Moreira EN, Duarte HSS, Cacique IS, Valente LA, Vieira RF, Paula Júnior TJ, Vale FXR (2014) Management of anthracnose in common bean by foliar sprays of potassium silicate, sodium molybdate, and fungicide. Plant Dis 98: 84-89. https://doi.org/10.1094/PDIS-03-13-0251-RE

Savvas D, Giotis D, Chatzieustratiou E, Bakea M, Patakioutas G (2009) Silicon supply in soilless cultivations of zucchini alleviates stress induced by salinity and powdery mildew infections. Environ Exp Bot 65:11-17. https://doi.org/10.1016/j.envexpbot.2008.07.004

Seebold KW, Datnoff LE, Correa-Victoria FJ, Kucharek TA, Snyder GH (2000) Effect of silicon rate and host resistance on blast, scald, and yield of upland rice. Plant Dis 84(8):871-876. https://doi.org/10. 1094/PDIS.2000.84.8.871

Zhang Q, Yan CL, Liu JC, Lu HL, Duan HH, Du JN, Wang WY (2014) Silicon alleviation of cadmium toxicity in mangrove (Avicennia marina) in relation to cadmium compartmentation. J Plant Growth Regul 33:233-242

Zhang M, Liang YC, Chu GX (2017) Applying silicate fertilizer increases both yield and quality of table grape (Vitis vinifera L.) grown on calcareous grey desert soil. Sci Hortic 225:757-763. https://doi.org/ 10.1016/j.scienta.2017.08.019 